\title{
Out of the Mediterranean? Post-glacial colonization pathways varied among cold-water coral species
}

Boavida Joana 1, 2, 3, ${ }^{*}$, Becheler Ronan 4, 5, 6, Choquet Marvin 4, 7, Frank Norbert ${ }^{8}$, Taviani Marco 9, 10, 11, Bourillet Jean-Francois ${ }^{12}$, Meistertzheim Anne-leila ${ }^{13,14}$, Grehan Anthony ${ }^{15}$, Savini Alessandra ${ }^{16}$, Arnaud-Haond Sophie ${ }^{1,15}$

${ }^{1}$ MARBEC, Institut Français de Recherche pour L'Exploitation de la MerUniv MontpellierCNRSIRD Sète ,France

2 Aix Marseille UniversitéCNRS/INSUUniversité de ToulonIRDMediterranean Institute of Oceanography (MIO) UM 110 Marseille ,France

${ }^{3}$ Centro de Ciências do MarUniversidade do Algarve Faro, Portugal

4 Institut Français de Recherche pour L'Exploitation de la MerCentre de BretagneREM/EEPLaboratoire

Environnement Profond Bretagne ,France

${ }^{5}$ CNRSUMI 3614 Evolutionary Biology and Ecology of AlgaeSorbonne UniversitéUPMC Univ Paris 6

Roscoff ,France

${ }^{6}$ Station Biologique de Roscoff ,Roscoff Cedex ,France

7 Faculty of Biosciences and AquacultureNord University Bodø ,Norway

8 Institute of Environmental PhysicsHeidelberg University Heidelberg ,Germany

9 Institute of Marine Sciences - National Research Council (ISMAR-CNR) Bologna, Italy

10 Biology DepartmentWoods Hole Oceanographic Institution Woods Hole Massachusetts, usa

${ }_{11}$ Stazione Zoologica Anton Dohrn Villa Comunale Naples, Italy

12 Institut Français de Recherche pour L'Exploitation de la MerPhysical Resources and Sea Floor Ecosystems Department Brest ,France

${ }^{13}$ CNRSSorbonne UniversitésLaboratoire d'Ecogéochimie des Environnements Benthiques (LECOB)

Banyuls-sur-Mer ,France

${ }_{14}$ CNRSSorbonne UniversitésLaboratoire d'Océanographie Microbienne (LOMIC) Banyuls-sur-

Mer ,France

${ }^{15}$ Department of Earth \& Ocean SciencesNUI Galway Galway ,Ireland

${ }^{16}$ Department of Earth and Environmental SciencesUniversità degli Studi di Milano-Bicocca

Milano, Italy

*Corresponding author : Joana Boavida, email address : joanarboavida@gmail.com

\section{Abstract :}

Aim

To infer cold-water corals' (CWC) post-glacial phylogeography and assess the role of Mediterranean Sea glacial refugia as origins for the recolonization of the northeastern Atlantic Ocean.

Location

Northeastern Atlantic Ocean and Mediterranean Sea. 
Taxon

Lophelia pertusa, Madrepora oculata.

Methods

We sampled CWC using remotely operated vehicles and one sediment core for coral and sediment dating. We characterized spatial genetic patterns (microsatellites and a nuclear gene fragment) using networks, clustering and measures of genetic differentiation.

Results

Inferences from microsatellite and sequence data were congruent, and showed a contrast between the two CWC species. Populations of L. pertusa present a dominant pioneer haplotype, local haplotype radiations and a majority of endemic variation in lower latitudes. Madrepora oculata populations are differentiated across the northeastern Atlantic and genetic lineages are poorly admixed even among neighbouring sites.

\section{Conclusions}

Our study shows contrasting post-glacial colonization pathways for two key habitat-forming species in the deep sea. The CWC L. pertusa has likely undertaken a long-range (post-glacial) recolonization of the northeastern Atlantic directly from refugia located along southern Europe (Mediterranean Sea or Gulf of Cadiz). In contrast, the stronger genetic differentiation of M. oculata populations mirrors the effects of long-term isolation in multiple refugia. We suggest that the distinct and genetically divergent, refugial populations initiated the post-glacial recolonization of the northeastern Atlantic margins, leading to a secondary contact in the northern range and reaching higher latitudes much later, in the late Holocene. This study highlights the need to disentangle the influences of present-day dispersal and evolutionary processes on the distribution of genetic polymorphisms, to unravel the influence of past and future environmental changes on the connectivity of cosmopolitan deep-sea ecosystems associated with CWC.

Keywords : cold-water corals, deep-sea, glacial marine refugia, Last Glacial Maximum, Lophelia pertusa, Madrepora oculata, marine phylogeography 
43 We are thankful to the teams involved in multiple oceanographic cruises: EU CoralFish's 44 ROV team and the captain and crew of BOBECO, IceCTD, and CE98. We thank Franck

45 Lartaud and Nadine Le Bris (chair 'Extreme environment, biodiversity and global change'

46 TOTAL Foundation and UPMC; Coord.: N. Le Bris) for providing Mediterranean samples, and

47 to Olivier Mouchel and Sandra Fuchs for their help during the BOBECO sampling. Thanks to

48 Lars-Eric Heimbürger for the English edits. JB was supported by the European Union's

49 H2020 research and innovation program under grant agreement Number: 678760 (ATLAS).

50 This work is a contribution to the European Union's FP7 and Horizon 2020 projects,

51 respectively CoralFISH (under grant agreement no. 213144) and ATLAS (under grant

52 agreement no. 678760), with samples from the Adriatic Sea through the EU Coconet

53 program. This is Ismar-CNR, Bologna scientific contribution n. 1960. This contribution reflects

54 the authors' views and the European Union is not responsible for any use that may be made

55 of the information it contains. 
87 Cold-water coral (CWC) reefs are among the most charismatic marine ecosystems in the deep ocean (>200 m), supporting abundant and diverse biomass (Milligan et al., 2016). Deep-reef habitats rely upon the frame-building capability of several coral species, notably Lophelia pertusa (Linnaeus, 1758) and Madrepora oculata (Linnaeus, 1758). These two species intermingle and anastomose in reefs in the northeastern Atlantic Ocean (NE Atlantic; Arnaud-Haond et al., 2017). However, constantly rising anthropogenic pressures in the deep-sea, such as fishery exploitation (Pusceddu et al., 2014), oil and gas exploitation (Cordes et al., 2016) and deep-sea mining (Wedding et al., 2015), threaten vulnerable CWC. Protection of key deep-sea ecosystems is, therefore, an urgent priority, particularly in the face of global change, and strategic Marine Protected Areas thoroughly assessed for their genetic connectivity, need to be established. Nonetheless, obtaining sufficient specimens and applying statistically robust sampling designs in genetic studies in the deep-sea remain challenging (Becheler et al., 2017). While CWC connectivity has been assessed along the North Atlantic Ocean at local and regional scales (LeGoff-Vitry et al., 2004; Morrison et al., 2011; Dahl et al., 2012; Becheler et al., 2017), effective conservation warrants information at the NE Atlantic basin scale (Fenberg et al., 2012). Spatial distribution analyses of genetic diversity can be used to detect connectivity pathways across reefs, and to define key areas for the conservation of biodiversity.

Similarly, the present-day geographic distribution of many terrestrial and marine species and their genetic diversity are influenced by environmental gradients, contemporary dispersal and recent climatic events, notably the Last Glacial Maximum (LGM, 26 - 19 ka; Hewitt, 1996, 1999, 2004; Petit et al., 2003; Maggs et al., 2008; Clark, 2009). Repeated Pleistocene glaciations are known to impact deep-sea ecosystems (Bouchet \& Taviani, 1992; Sabelli \& Taviani, 2014; Vertino et al., 2014). However, their impact on CWC in particular remains understudied. The responses of deep-sea species may not be similar to those of coastal species, because biological assemblages, environmental gradients and dispersal patterns are fundamentally different among ecosystems and geographical areas (Kousteni et al.,

114 2015; Shum et al., 2015). after Pleistocene (ca. 2.7 Ma to $12 \mathrm{ka}$ ) glacial events can partially be inferred from paleorecords (Supplementary Paleo-history in Appendix S1). While CWC have maintained a 
continuous presence in the Mediterranean Sea since at least the early Pleistocene (Vertino et al., 2014), in the NE Atlantic CWC presence may have been more affected by changes in climate, with a consequent local demise during the LGM (Frank et al., 2011). Notably, the last cold oscillation, during the Younger Dryas (12.9-11.7 ka), represented a favourable period for CWC reef growth in the western Mediterranean Sea, as well as in adjacent Atlantic regions in the Gulf of Cadiz and African margins (Schröder-Ritzrau et al., 2005; McCulloch et al., 2010; Taviani et al., 2011). In contrast, growth episodes of CWC in the NE Atlantic have been restricted to warm climate stages and coral fossils are absent from strata corresponding to glacial episodes (Frank et al., 2009). Radiometric dating shows that NE Atlantic CWC are younger than those from the Mediterranean Sea, with ages estimated to be post-LGM (under 12,000 years; Freiwald \& Roberts, 2005; Schröder-Ritzrau et al., 2005), producing an NE Atlantic CWC age gradient from south to north (summarized in Fig. 1). Given the persistent occurrence of CWC, it has been argued that the Mediterranean basin may have acted as a CWC glacial refugium during range contractions in the North Atlantic Ocean during Pleistocene glaciations (De Mol et al., 2002; Henry et al., 2014). This refugium may have constituted the source for the Atlantic northward recolonisation of CWC at the end of the LGM by larvae, which were transported with intense flows of Mediterranean Outflow Water (MOW) beginning in 50 ka (Fig. 1; Voelker et al., 2006; Stumpf et al., 2010).

The sympatric paleo-coral occurrence of $L$. pertusa and $M$. oculata suggests a common history of these species in terms of range contraction and expansion. This common response to past environmental change may not hold true in light of recent studies (Lartaud et al., 2014,2017 ) pointing to physiological differences between both species, particularly in terms of optimal growth temperatures. The two CWC may demonstrate dissimilar ecological strategies. Lophelia pertusa presents potential for widespread larval dispersal (Strömberg and Larsson, 2017), high fecundity (Waller \& Tyler, 2005) and variable microbiome compositions (Meistertzheim et al., 2016). The reproductive strategy of $M$. oculata is different from that of $L$. pertusa, with much lower fecundity (Waller \& Tyler, 2005) and a resilient microbiome (Meistertzheim et al., 2016; and unknown larval characteristics). Although reduced genetic connectivity has been demonstrated for $L$. pertusa at an inter-basin scale, along with moderate to high gene flow within regions (Morrison et al., 2011; Dahl et al., 2012; Flot et al., 2013), the extent of CWC connectivity along the European margins and the role that extant populations had in the past remain to be tested. Here, we investigate the population genetic diversity and structure of $L$. pertusa and $M$. oculata along the deep margins of the NE Atlantic using nuclear data (microsatellites and sequences). We discuss how past environmental variations related to the LGM may have affected the genetic diversity and structure of the two CWC species across this wide geographic region. We hypothesise that distinct ecological requirements in the deep-sea influenced population structure and the distribution of genetic diversity within species. In particular, we expected that $L$. pertusa would present low levels of population differentiation across the NE Atlantic margins, consistent with a post-LGM northward expansion from southern refugia and maintained by present-day connectivity. We expected $M$. oculata to present stronger population differentiation than $L$ pertusa, consistent with the lower fecundity of $M$. oculata. To these aims, we examined the genetic structure and diversity of $L$. pertusa and $M$. oculata within and among the principal biogeographic provinces of the NE Atlantic and the Mediterranean Sea where CWC are known to occur. 


\section{Materials and methods}

\subsection{Field collections}

165

166

167

168

169

170

171

172

173

174

175

176

177

178

179

180

181

182

183

184

185

186

187

Two hundred and seventy samples of Lophelia pertusa and 260 samples of Madrepora oculata were collected during the period of 2007-2012 from six regions between 250 and 1,170 m depth: the eastern Mediterranean basin (Ionian Sea, south-eastern Adriatic Sea), western Mediterranean basin (Gulf of Lions); Mid-Atlantic region (Azores), Bay of Biscay, SE Rockall Bank (off western Ireland), and the High latitudes (Iceland) (Fig. 1; Table S1 in Appendix S1). In one canyon of the Bay of Biscay, Petite Sole, two sample collections were conducted at different sections of the canyon. Samples were stored in $96 \%$ ethanol and frozen at -20 or $-80^{\circ} \mathrm{C}$ prior to DNA extraction. Lophelia pertusa DNA was extracted aboard using the Fast DNA®SPIN for soil kit, according to the manufacturer's protocol (MP Biomedicals, France); for M. oculata we used cetyl trimethyl ammonium bromide for DNA extraction (Doyle \& Doyle, 1988). Sampling permits for the Bay of Biscay, Rockall bank and Iceland were obtained for the entire cruise by the fleet manager (IFREMER; No 347/11; NV/USEN/No 3278/2012); in the Mediterranean Sea sampling was conducted in compliance with all relevant regulations for national and international waters; the Azores samples were collected as fishing by-catch without the need for permits.

\subsection{Core collection and dating}

Within the Guilvinec Canyon (Bay of Biscay), a 1.2 m-length sediment core (BBCO-CS01) was collected (N4656,045'; W005 $\left.{ }^{\circ} 21,642^{\prime}\right)$ at $815 \mathrm{~m}$-depth. The core was representative of the superficial layers of the Armorican margin. The skeleton remains of corals were dated using the U/Th method at the Institute for Environmental Physics at Heidelberg University (Schröder-Ritzrau et al., 2003). Foraminifera from nearby sediments were ${ }^{14} \mathrm{C}$-dated. Corals and foraminifera were subsequently calibrated to absolute ages using Intcal13 (Reimer et al., 2013).

\subsection{DNA amplification and sequencing}

The internal transcribed spacer (ITS) ribosomal sequence was amplified using primers developed by Diekmann et al. (2001). ITS sequences (262 samples of $L$. pertusa 1130 base pair, bp, 200 samples of M. oculata $1124 \mathrm{bp}$ ) were proofread and aligned using Geneious v6.1 (Kearse et al., 2012). Nine L. pertusa (Morrison et al., 2008; Becheler et al., 2017) and six M. oculata microsatellite markers were amplified following Becheler et al. (2017). Products were scored using GenEIOUS v5.6.4. One L. pertusa locus was discarded due to the high frequency of null alleles $(>30 \%)$. Clones were removed from each dataset (ITS and microsatellites). Statistical power was assessed for the two coral species (Supplementary Methods S2 in Appendix S1). Only sites with five or more samples were kept for analyses.

\subsection{Phylogeographic patterns and genetic diversity}

Population genetic differentiation for ITS sequences was assessed with the pairwise haplotype $F_{S T}$ statistic (Weir \& Cockerham, 1984) in ARLEQUIN v3 (Excoffier et al., 2005). The distribution of genetic variability within and among groups was estimated with analysis of molecular variance (AMOVA) in ARLEQUIN on four groups for L. pertusa, and on five groups for M. oculata (1. Mediterranean, 2. Bay of Biscay, 3. SE Rockall Bank and 4. High Latitudes, and 5. Mid-Atlantic). Population genetic diversity was estimated with i. the number of distinct and private haplotypes, ii. number of polymorphic sites, iii. haplotypic diversity (Nei, 1987), 
and iv. the mean number of pairwise differences (Tajima, 1983). Haplotype relationships were visualized with statistical parsimony networks on TCS v1.21 (Clement et al., 2000)

Microsatellite genetic diversity and structure were estimated with GENETIX v4.05 (Belkhir K., Borsa P., Chikhi L., 2004). The mean number of alleles per locus was standardized to the lowest number of samples collected; estimates of observed $\left(\mathrm{H}_{\mathrm{O}}\right)$ and unbiased $\left(\mathrm{H}_{\mathrm{E}}\right)$ multilocus heterozygosity (Nei, 1978), the $\mathrm{F}_{\mathrm{IS}}$-statistic and its significance (tested with 1000 permutations), and linkage disequilibrium, which was assessed through the index $\check{r}_{d}$ with MULTILOCUS v1.3 (http://www.bio.ic.ac.uk/evolve/software/multilocus/), were calculated. Genetic structure (pairwise $F_{S T}$ ) was estimated with $\theta$ (Weir \& Cockerham, 1984). Inference of spatial population structure with Bayesian clustering was performed with TESS v2.3 (François et al., 2006; Chen et al., 2007) via the 'tess3r' R package (Caye et al., 2016; The R Foundation for Statistical Computing, 2018).

We used discriminant analysis of principle components (DAPC; Jombart et al., 2010) implemented in the R package 'adegenet' (Jombart, 2008), to determine whether the genotypes of $L$. pertusa and $M$. oculata were distinct between different sampling sites. We used k-means clustering ( $\mathrm{k}=2$ to maximum number of sampling sites) with the Bayesian information criterion $(B I C)$ to identify the optimal number of genetic clusters describing the data. The a-score optimisation procedure was used to identify the optimal number of principal components (PCs) to retain (retaining too many PCs can lead to overfitting the discriminant functions). a-score optimisation showed that approximately 25 PCs needed to be retained for M. oculata ( $>69.3 \%$ of the total variance), and $60 \mathrm{PCs}$ needed to be retained for L. pertusa (28.9\%). Next, we used DAPC to derive membership probabilities for each individual in each of the groups using location priors (see Supplementary methods $\mathrm{S} 2$ in 230 Appendix S1).

\subsection{Demographic inferences}

232 Historical fluctuations in population size for each sampled site were detected using Fu's Fs 233 (Fu, 1996) and Tajima's D (Tajima, 1989) on ITS data from L. pertusa and M. oculata. Departures from mutation-drift equilibrium were tested with ARLEQUIN under the null hypothesis of no significant change in effective population size. A negative value significantly different from constant population size was interpreted as a signature of population expansion; the significance of $F s$ and $D$ values was determined by randomization.

238 The evolutionary and demographic histories of NE Atlantic and Mediterranean CWC 239 (L. pertusa and M. oculata) were further reconstructed using approximate Bayesian 240 computations (ABC) implemented in DIYABC v2.1.0 (Cornuet et al., 2014). We used 241 microsatellite and ITS sequence data for $M$. oculata and microsatellite data only for L. pertusa. Lophelia pertusa populations were grouped according to microsatellite Bayesian clustering (cluster 1 - Eastern Mediterranean, cluster 2 - Western Mediterranean, cluster 3 Bay of Biscay and High latitudes, cluster 4 - SE Rockall bank), and for M. oculata, we used the geography-based population grouping (models of $L$. pertusa using geography-based population groups along with further details are found in Appendix S1). We compared competing scenarios in order to identify the patterns of post-LGM CWC range expansion along the NE Atlantic margins. Scenarios 1,2 and 4 determined the pattern of colonisation of the northern edge of the NE Atlantic range, comparing models of stepping-stone colonization from the Mediterranean Sea to the Bay of Biscay and then further north (Scenario 1 stepwise range expansion), and models of admixture between the Bay of Biscay, High latitudes and West Mediterranean to produce the SE Rockall bank population (Scenario 2, L. pertusa), between the High latitudes and SE Rockall bank to produce the Mid-Atlantic 
population (Scenario 2, M. oculata), between the Bay of Biscay and SE Rockall bank to produce the Mid-Atlantic population (Scenario 4, M. oculata), and between the Mediterranean Sea and the Bay of Biscay to produce the Mid-Atlantic population (Scenario 5, M. oculata). Scenario 3 examined the demographic history of the NE Atlantic and Mediterranean populations with changes in population size since colonisation. We compared a null model of no change in population size (Scenarios 1 and 2) to a model of a short bottleneck (10 generations) during colonisation followed by population expansion (Scenario 3 ). In this scenario, at each split, there is an initial reduction in the size of the newly formed population because the expansion is assumed to start with few immigrants. For $L$. pertusa, we used the geologically inferred time of SE Rockall bank colonisation (approx. 9 ka; Frank et al., 2009) to calibrate divergence times (mode and 95\% confidence interval) from the estimated ABC number of generations; we then assumed the same generation time (est. approx. 3 years) for M. oculata.

We generated 3 to $5 \times 10^{6}$ simulations for each scenario tested using the combined microsatellite and ITS datasets for M. oculata and the microsatellite dataset for L. pertusa (Supplementary methods S2 in Appendix S1) to produce a set of pseudo-observed datasets (PODs). Effective population sizes and parameters for the generalized stepwise mutation and Kimura two-parameter models were set to default values, while the time of population divergence (in generations) was defined as uniform within post-LGM periods (for model parameters, see Supplementary Methods S2 in Appendix S1). The posterior probability of each scenario was inferred with a logistic regression performed on the $1 \%$ of PODs closest to the empirical data. We empirically evaluated the power of the model to discriminate among scenarios using a Monte Carlo estimation of false allocation rates (type 1 and 2 errors) resulting from $A B C$ posterior probability-based model selection.

Supplementary Methods can be found in the Appendix S1.

\section{3. Results}

\subsection{Core collection and dating}

Fossils of Lophelia pertusa and Madrepora oculata were found in the gravity core. The dating of CWC remains revealed ages ranging from present to $6,959 \pm 169$ years (U/Th corrected age).

\subsection{Phylogeographic patterns and genetic diversity}

TESS analyses showed Lophelia pertusa had four genetically distinct groups: the eastern and the western Mediterranean Sea, the SE Rockall bank and the remaining NE Atlantic populations (Bay of Biscay and High latitudes; Fig. 2a right). Within L. pertusa, the Mediterranean genetic ancestry, in particular the West Mediterranean ancestry (blue), had low proportions across all NE Atlantic sites. The green genetic ancestry was maximized in the Bay of Biscay and High latitude populations, while the grey genetic ancestry (found in the Bay of Biscay and High latitudes sites) was maximized in the SE Rockall bank population. The grey ancestry component was present in high proportions in the High latitude populations, particularly in Hafadsjup (Iceland, HAF), where it comprised over half of the L. pertusa ancestry.

The genetic differentiation estimated through AMOVA and pairwise $F_{S T}$ (Table S4.1 and S5.1 in Appendix S1) was strong between the East and West Mediterranean populations and weak across the NE Atlantic samples, with almost no values significantly different from zero. The SE Rockall bank population was differentiated from over half of the Bay of Biscay locations but not from the High latitude populations (Table S5.1 in Appendix S1). 
Clustering performed with TESS showed that $M$. oculata was also structured in four genetic clusters but with a different organisation (Fig. 2a). The Mediterranean Sea and the High Latitudes formed two distinct clusters (displayed in red and grey in Fig. 2a left). The next two clusters were less geographically coherent: the Bay of Biscay genetic ancestry (blue; third cluster) was nearly absent from the Lampaul canyon population, as well as from the SE Rockall bank and Mid-Atlantic populations (which together form the fourth cluster). M. oculata populations from the Bay of Biscay harboured a strong Mediterranean genetic component (red) maximized in the populations of the northern Bay of Biscay canyons (Morgat, Crozon and Petite Sole) but absent from most individuals in the Mid-Atlantic, Lampaul canyon (in the Bay of Biscay) and SE Rockall bank populations. The NE Atlantic genetic ancestry (green) was well represented in all NE Atlantic populations and in smaller proportions in some Mediterranean individuals. High latitude genetic ancestry (grey) was found in high proportions in the SE Rockall and Mid-Atlantic populations.

313 The mean pairwise $F_{S T}$ between regions was high for $M$. oculata, with a value up to 0.5 between the eastern Mediterranean Sea and High Latitudes, but not significantly different from zero between the eastern and western Mediterranean Sea populations, while nearly all pairwise $F_{S T}$ values were significantly different from zero (Table S4.2 and S5.2 in appendix). A lack of population differentiation was observed between two Bay of Biscay canyons (CRZLMP), within one canyon (PS1-PS2), between High latitude locations, and between SE Rockall bank and its closest High latitude site, Londsjup (Table S5.2 in Appendix S1). The regional $F_{S T}$ was significantly different from zero for all pairwise comparisons for the two coral species: Mediterranean Sea, Mid-Atlantic, Bay of Biscay, SE Rockall bank and High latitudes. The lowest regional $F_{S T}$ for $M$. oculata was between the High latitude and SE Rockall bank populations (0.051), while that for L. pertusa was between the High latitude and Bay of Biscay populations (0.004).

The genetic affinities of the sampled individual corals were projected onto principal components (DAPC). For $L$. pertusa, as expected considering the clustering and $F_{S T}$ results, the first axis separates the Mediterranean and NE Atlantic populations. Within each group, genetic variability is spread across the second axis, with the eastern Mediterranean samples at one end and the western Mediterranean samples at the other end; this separation is also clearly visible in the group membership probabilities (in the bottom of Fig. 3b). The NE Atlantic genetic group along PC2 spans samples from the Bay of Biscay to the High latitudes, including the SE Rockall bank (Fig. 3b). For M. oculata genetic affinities show a cline on the first axis, separating samples from the lower (Mediterranean) to the higher latitudes. The gradient is visible in the group membership proportions shown in the bottom of Fig. 3a, particularly along the Bay of Biscay canyons and along SE Rockall-High latitude populations.

The gene diversity and the average number of alleles per locus for $L$. pertusa and $M$. oculata samples were high and moderate, respectively ( $L$. pertusa $\mathrm{H}_{\mathrm{E}} 0.90+/-0.08$, and 30.4 alleles per locus; M. oculata $\mathrm{H}_{\mathrm{E}} 0.53+/-0.23$ and 12.3 alleles per locus; Tables 1 and 2). Regionally, the average allelic richness was higher at intermediate latitudes for both species

(Mediterranean: 7 for L. pertusa and 3 for M. oculata, Bay of Biscay: 16 and 5, SE Rockall Bank: 15 and 6, and High Latitudes: 12 and 4, in the Mid-Atlantic where only M. oculata was sampled: 3). Private alleles were present in all sampled $L$. pertusa sites, but were rarely present in M. oculata populations. Madrepora oculata presented higher private allelic richness in the Mediterranean basin (2-4). An excess of homozygotes was observed in all $L$. pertusa populations and in half of the M. oculata sites, particularly along the NE Atlantic populations.

347 The patterns of genetic structure inferred with ITS were generally concordant with those of 348 microsatellites. Based on statistical parsimony, a haplotype network was constructed for 
L. pertusa, with one main ITS lineage inferred as the most likely ancestral haplotype (from a total of 39 haplotypes), which possibly radiated from lower to higher latitudes ( $>60 \%$ of samples), and many rare haplotypes (over 20 unique). The ancestral haplotype was nearly absent from SE Rockall bank L. pertusa, supporting the Bayesian clustering, where High latitude and Bay of Biscay samples shared a genetic ancestry (green) almost absent from SE Rockall bank samples. Two other well-represented haplotypes were restricted to i) the Bay of Biscay, High Latitudes and Mediterranean Sea, and ii) mostly the SE Rockall Bank; with a few Bay of Biscay samples (Fig. 2b), supporting the Rockall bank genetic ancestry (grey) as distinct from relatively close populations (Bay of Biscay and High latitudes). The Atlantic sites harboured the majority of sequence variation. The Bay of Biscay had the highest number of haplotypes (24), with 12 unique to this region, but the highest haplotype diversity $(\mathrm{H}=0.7)$ was found in the West Mediterranean Sea (Table 3). Ten haplotypes were observed in the Mediterranean Sea, with two unique to the western Mediterranean. Iceland, regardless of its high latitude and recent CWC fossil ages ( $8.3 \mathrm{Ka}$, Fig. 1), harboured the second highest number of $L$. pertusa haplotypes (14; Table S6 in Appendix S1), with two haplotypes exclusive to its CWC reefs. L. pertusa haplotypes were not particularly clustered, and, except for the inferred ancestral haplotype, most haplotypes were found in moderate to low frequencies at each site (Table S8 in Appendix S1). There were no L. pertusa region-specific haplotypes in the Bay of Biscay or the West Mediterranean Sea.

There was some phylogeographic clustering for the M. oculata haplotype network, with one lineage dominant in the High latitudes and SE Rockall bank, modestly present in distant southern geographic locations (e.g., one sample from the Mediterranean Sea), and absent from the Bay of Biscay. A quarter of all haplotypes were shared across distant geographic regions (i.e., High Latitudes and Mediterranean Sea). Haplotypes found in Mid-Atlantic $M$. oculata were also found in all other regions (one haplotype) or were restricted to the Bay of Biscay and SE Rockall bank (two haplotypes), with one haplotype unique to the MidAtlantic site. Private (unique) haplotypes were observed in all regions where $M$. oculata was sampled but not at all sites. Seven haplotypes were well represented, and there was no obvious sign of haplotype radiation (Fig. 2b). Similar to $L$. pertusa, the majority of ITS sequence variation for $M$. oculata occurred in Atlantic sites. The Bay of Biscay and SE Rockall bank presented the highest number of haplotypes (15 and 11, respectively) and the only region-specific haplotype (Table S8 in Appendix S1). Nonetheless, the highest haplotype diversity $(\mathrm{H}=0.9)$ was observed in M. oculata from the Mid-Atlantic.

The populations of $L$. pertusa in the NE Atlantic were slightly differentiated, while within the Bay of Biscay, the genetic structure was weak for $M$. oculata (nearly all pairwise $F_{S T}$ not significantly different from zero; Table S4 in Appendix S1). Madrepora oculata showed a regional pattern of population genetic structure concordant with microsatellite analyses (high $F_{S T}$ between populations from distinct regions). Overall, $5 \%$ of $L$. pertusa and nearly $40 \%$ of M. oculata genetic variation occurred among regions (AMOVA; Table S7 in Appendix S1).

Haplotypic and molecular diversities varied among locations (Tables 3 and 4). For L. pertusa, haplotypic diversity was high (up to 0.6 in the NE Atlantic and up to 0.7 in the Mediterranean Sea) due to haplotype radiations. Haplotypic diversity was also high in $M$. oculata populations (0.3-0.7 in High Latitudes, 0.9 in the Mid-Atlantic site, where there were four haplotypes for five individuals). A comparable pattern of variation of molecular diversity is observed for both species. Nucleotide diversity was lower at the NE Atlantic sites than at the Mediterranean Sea sites for L. pertusa. For M. oculata, nucleotide diversity was highest in the West Mediterranean and Mid-Atlantic populations.

\subsection{Demographic inferences}


The tests of conformity to selective neutrality suggest different demographic histories for $L$. pertusa and $M$. oculata. The Mediterranean populations of $L$. pertusa did not significantly depart from mutation-drift equilibrium (Table 3), while most populations in the Bay of Biscay showed negative Fs and Tajima $D$ values significantly departing from mutation-drift equilibrium. This result is consistent with the network and indicates a recent demographic expansion of the Atlantic populations. All Fs values and most Tajima D values were nonsignificant for M. oculata; only two $M$. oculata sites showed Tajima $D$ values significantly departing from constant effective population size, indicating a demographic expansion: one site in the East Mediterranean and one site in the Bay of Biscay (Crozon canyon; Tables 3 and 4).

407 Model-based inference pointed to an ancient (up to $30 \mathrm{ka}$; Table S2 in Appendix S1) divergence of the East and West Mediterranean Sea L. pertusa populations, as observed with DAPC. The West Mediterranean population was identified as the source from which all other NE Atlantic populations emerged, either directly (Bay of Biscay and High latitudes; approx. $21 \mathrm{ka}$ ) or through admixture (SE Rockall bank; much later at $9 \mathrm{ka}$ ), in line with the Bayesian clustering, where the West Mediterranean ancestry (blue) is found throughout the Atlantic sites, and with the ITS network, where most Mediterranean haplotypes are shared with Bay of Biscay corals. The shared SE Rockall genetic ancestry (grey) between the Bay of Biscay and the High latitude populations identified with Bayesian clustering agrees with the admixed origin for the SE Rockall $L$. pertusa found with ABC. The Mediterranean population size estimates $(\mathrm{N}=2,500$ to 7,000$)$ were much smaller than the NE Atlantic size estimates $(\mathrm{N}=70,000-85,000)$. The Bay of Biscay demographic expansion scenario with admixture was supported with a high probability relative to the approximately 0.2 support for scenarios of stepping-stone colonisation and changes in population size (Figs. S3-S4 in Appendix S1). The scenario choice confidence was high, with low error rates (posterior predictive error = 0.29). Post-LGM range colonisation followed a long-range model of northern range colonisation, whereby the Bay of Biscay and High latitudes were colonised directly from the West Mediterranean Sea populations, while at a later stage the SE Rockall bank was colonised from admixture between Bay of Biscay, High latitude and West Mediterranean populations (Fig. 1 bottom inset).

$A B C$ analyses indicated that the Mediterranean Sea $M$. oculata populations were the main source population $(\mathrm{N}=8,600)$ from which all other NE Atlantic populations emerged. The Mediterranean source population scenario, with colonisation of the Atlantic margins via the Bay of Biscay agrees with Bayesian clustering, where the Mediterranean genetic ancestry (red) is found in moderate proportions in the Bay of Biscay populations and is absent from the Mid-Atlantic and SE Rockall populations. The scenario of a Mediterranean source population with colonisation of the NE Atlantic and admixture was supported with high probability $(0.9)$ relative to the low support for the scenarios of changes in population size or competing admixture (Figs. S3-S4 in Appendix S1). The scenario choice confidence was high, with low error rates (0.30). Post-LGM range colonisation along the European margins followed a stepping-stone model of northern range colonisation, whereby the Bay of Biscay was colonised directly from Mediterranean Sea populations (22 ka), while the Bay of Biscay M. oculata later colonised the SE Rockall bank (7 ka). The SE Rockall bank populations then originated other NE Atlantic M. oculata populations. This occurred either through admixture with the Bay of Biscay (Mid-Atlantic) only approximately 2 ka or directly (High latitudes) much more recently ( $0.3 \mathrm{ka}$; Fig. 1 top inset). The genetic footprint of those events can be seen in the main haplotype shared between High latitudes and SE Rockall corals but absent from Bay of Biscay corals, by a haplotype restricted to the Bay of Biscay, SE Rockall bank and Mid-Atlantic (haplotype V in Figure S6 Appendix S1), and by the position of Mid-Atlantic samples in the DAPC between SE Rockall and Biscay samples. 
448 Although the deep-sea is considered as relatively environmentally stable over time, there is

449

450

451

452

453

454

455

456

457

458

459

460

461

462

463

464

465

466

467

468

469

470

471

472

473

474

475

476

477

478

479

480

481

482

483

484

485

486

487

488

489

490

491

492

493

494

evidence that CWC have undergone demographic changes similar to those experienced by their coastal water counterparts (Wilson \& Eigenmann Veraguth, 2010; Sabelli \& Taviani, 2014; Vertino et al., 2014; Quattrini et al., 2015). Here, we focused on the LGM and explored two scenarios that could explain the observed patterns of genetic diversity and structure for L. pertusa and M. oculata, respectively:

i) Before the LGM (to approximately $50 \mathrm{ka}$, which is the oldest period represented by existing data), NE Atlantic populations were absent from the current northern range of their modern distribution, and present-day patterns of genetic variation were caused by expansion northwards, most likely originated from the West Mediterranean Sea and/or adjacent NW coast of Africa and a later Mediterranean-NE Atlantic admixture;

ii) Before the LGM, NE Atlantic populations were absent from the current northern range of their modern distribution and present-day patterns of genetic variation were caused by "stepping-stone" northwards colonisation with modest demographic expansions and by a much later admixture between NE Atlantic populations with possible contributions from other unsampled populations.

\section{Scenario i)}

Geological studies report the absence of deep CWC reef growth in the NE Atlantic during glaciations of the Late Pleistocene (approx. 126 - $12 \mathrm{ka}$; with the Last Glacial Maximum approx. 26.5-19 ka; Clark et al., 2009; Frank et al., 2009). In contrast, between 50-12 ka, L. pertusa reefs flourished in the Mediterranean Sea (Supplementary Paleo-History in Appendix S1). The Mediterranean Outflow Water (MOW 800-1300 m depth; Price et al., 1993) volumes in this period were smaller than those at present (Rogerson et al., 2004) but concentrated in channels with high local flow (Zahn et al., 1997). In the Gulf of Cadiz and on the Moroccan shelf, reef growth was estimated to have started at approximately 40-50 ka (Fig. 1), when glacial conditions were particularly favourable for coral growth, unlike in the NE Atlantic (Schröder-Ritzrau et al., 2005; Eisele et al., 2011; Ramos et al., 2017; Weinberg et al., 2018). The rapid increase in post-glacial Atlantic Meridional Overturning Circulation resulted in increased transport of suspended particles and is speculated to have boosted the expansion of $L$. pertusa from these southern locations (Mediterranean Sea and/or adjacent NW coast of Africa) into the NE Atlantic (Eisele et al., 2011; Fink et al., 2013; Henry et al., 2014).

According to geological analysis, continuous and vertical growth of CWC reefs occurred in the Bay of Biscay area during at least the past 7,000 years. Genetic evidence of recent L. pertusa demographic expansions in the Bay of Biscay, at the end of the LGM (approx. 21 $\mathrm{ka}$ ) is substantiated by internal transcribed spacer sequences with haplotype network and conformity tests and attributed to a founder event, i.e., a dominant haplotype found in all regions (from the Mediterranean Sea to the High Latitudes). Such a demographic expansion would have produced satellite haplotypes with a low genetic distance, as observed in L. pertusa. The vast nearly panmictic ensemble occurring along the NE Atlantic indicates a recent common history for Atlantic $L$. pertusa reefs. This is supported by studies of reproduction and larval development that indicate that $L$. pertusa larvae have a long pelagic larval duration, suggesting a high dispersal potential (Waller \& Tyler, 2005; Larsson et al., 2014; Strömberg \& Larsson, 2017). Larvae of L. pertusa maintained in aquaria have been observed swimming towards the surface, yet it remains unknown whether they are neutrally buoyant and remain at spawning depth in their natural environment, i.e., at the depth of the North Atlantic currents shown in Fig. 1. Larval dispersal trajectories may track specific water 
masses (Dullo et al., 2008) occurring at intermediate depths with potential settling sites. Such a high larval dispersal ability may have favoured large-scale expansion, explaining widely shared genetic ancestry, such as that between L. pertusa in the Bay of Biscay and High latitudes.

The genetic distinctiveness of SE Rockall bank L. pertusa (observed in microsatellites and ITS loci) indicates a more complicated history. The rarity of the dominant haplotype in SE Rockall bank suggests either another source for colonisation or strong post-colonisation drift. Approximate Bayesian computation favours an evolutionary scenario whereby the SE Rockall population is colonised via admixture of the Bay of Biscay group and West Mediterranean corals at approximately the time of the onset of the modern Atlantic Meridional Overturning Circulation (AMOC; Repschläger et al., 2017). Mediterranean Water travelling northwards along the Iberian Peninsula and Bay of Biscay does not reach the SE Rockall bank (Frank et al., 2009). Instead, SE Rockall hydrodynamics are more influenced by northward moving Atlantic waters, including the rich North Atlantic Current (NAC). The NAC is part of the Gulf Stream, which may provide occasional genetic material from the West North Atlantic L. pertusa reefs (Morrison et al., 2011). Analyses encompassing the full distributional range of $L$. pertusa are essential to clarify missing links in population relatedness at trans-Atlantic scales.

The ancient divergence of Mediterranean L. pertusa populations from the eastern and western basins estimated by the $\mathrm{ABC}$ model to have taken place during the Last Glacial Maximum (approximately $24 \mathrm{ka}$ ) is reasonable. In the temperate Eastern Atlantic, including the Mediterranean Sea, CWC growth persisted over glacial-interglacial cycles (Frank et al., 2011). This steady allopatry may have been maintained by vicariance driven by ocean currents acting upon the earliest life stage of $L$. pertusa or by local adaptations. Finer-scale analyses are needed to identify and quantify the importance of such variables. All together, the data support a post-glacial recolonisation of the NE Atlantic by L. pertusa. Mediterranean L. pertusa are divergent from most NE Atlantic populations (ITS, microsatellites). Given that sampling is at best partial, it is difficult to speculate about the precise origin of the NE Atlantic populations. The Mediterranean lineages and genotypes found in low proportions across the NE Atlantic reefs and the high haplotypic diversity mainly in the western basin of the Mediterranean Sea, concur with ABC analyses that the glacial refugia for NE Atlantic L. pertusa colonisation may have been in the West Mediterranean Sea or in adjacent regions (e.g., the coral mounds in the Gulf of Cadiz and NW Africa; Eisele et al., 2011). Lophelia pertusa populations in this region thrived during glacial periods and might have provided larvae that dispersed in Mediterranean Water northwards towards the Bay of Biscay (Fig. 1).

In contrast, $M$. oculata populations are more strongly structured and there is no evidence of a large demographic expansion.

\section{Scenario ii)}

Concurrent to L. pertusa, Mediterranean Sea M. oculata populations were the main source from which all other NE Atlantic populations emerged around the end of the LGM, as estimated by model-based inference (Fig. 1 top inset). Mediterranean M. oculata, having persisted during glacial periods (Gulf of Cadiz, NW Africa), thus represent a putative LGM refugium, possibly in combination with unsampled adjacent populations. For $L$. pertusa, the absence of samples from the NW coast of Africa prevented the role of this potential refugium from being inferred. The estimated time for NE Atlantic colonisation, approximately $21 \mathrm{ka}$, suggests that Mediterranean $M$. oculata represent a "stable rear-edge" population (Hampe \& 
542 Petit 2005). The Mediterranean harbours high levels of DNA diversity and the greatest

543 number of unique haplotypes and private alleles, a testament to the long-term stability of

544 Mediterranean populations (Hewitt 2000). However, unlike L. pertusa, there is no substantial

545 differentiation of East and West Mediterranean M. oculata, a difference possibly linked to

546 differences in the population size or reproductive or early life traits of these species.

547 Information on reproduction and early life history is needed to reduce model uncertainty and

548 allow a better understanding of CWC past and present connectivity.

549 Analyses gave the most support to the hypothesis that $M$. oculata's northern range edge was

550

551

552

553

554

555

556

557

558

559

560

561

562

563

564

565

566

567

568

569

570

571

572

573

574

575

576

577 colonised in a stepping-stone manner (Bay of Biscay, followed by SE Rockall and later the High latitudes) instead of via long-range colonisation directly from glacial refugia, as supported in the case of the L. pertusa northern populations. Unique haplotypes were almost evenly spread across the distribution range, suggesting that $M$. oculata maintained other glacial (cryptic) refugia throughout its current range and underwent only localized, modest, post-glacial expansions. This resulted in the co-existence of divergent genetic lineages across the NE Atlantic, i.e., one lineage dominating the higher latitudes and another lineage in the Bay of Biscay, both with a lower frequency in other regions. This pattern is consistent with the persistence of $M$. oculata in several distinct areas, locally or regionally, followed by the redistribution of divergent lineages after periods of allopatry (Petit et al., 2003). The low occurrence of unique haplotypes and alleles is the result of relatively recent admixture and colonisation events (Mid-Atlantic, High latitudes), which $A B C$ analysis indicates took place during the late Holocene. The large-scale spatial genetic structure would then have been shaped by refugium-driven vicariance. Long-distance dispersal and gene flow, which would erase patterns of population structure may be unlikely in $M$. oculata. This may be the case if this species of CWC presents different reproduction and dispersal modes compared to L. pertusa, e.g., a shorter pelagic larval duration or brooding in M oculata than in L. pertusa. This hypothesised poor dispersal ability of $M$. oculata may be associated with the complex habitat geomorphology (canyons, seamounts) along the NE Atlantic, along with the large depth gradient (hundreds to thousands of metres) and may contribute to fragmentation, reduce gene flow and maintain or reinforce large-scale patterns of the NE Atlantic population structure in M. oculata. For instance, Lampaul canyon has the highest composition of soft substrate and a near absence of coral framework compared to the other Bay of Biscay canyons studied here (van den Beld et al., 2017). Such differences may have created (past) barriers to gene flow. However, separating the exact effects of geography and the environment on population structure is difficult, and this study identified no clear relationship between divergence and depth. Finer-scale analyses are needed to identify and quantify the contributions of environmental variables and putative allopatric refugia.

The formation of the admixed Mid-Atlantic population of M. oculata (Fig. 2) was dated to c. 2 ka (0.7-11 ka); even accounting for the wide confidence interval of the estimated time, this period is well within the Holocene. During this period, the modern AMOC was established and might have contributed to the colonisation of deep coral habitats along the Mid-Atlantic Ridge and/or to admixture with older populations from either the European margins (SE Rockall bank, Bay of Biscay canyons) or the NW Atlantic (not sampled here). The southward branch of the vigorous NAC may have favoured the link between the European margins and the Mid-Atlantic. The absence of Mediterranean ancestry and the level of High latitudes ancestry in the Mid-Atlantic and SE Rockall regions suggest limited connection with Mediterranean populations. The fact that genetic polymorphism is consistently shared between European margins and the Mid-Atlantic makes it tempting to speculate on the colonisation or introgression of the Mid-Atlantic by some NE Atlantic populations. However, such a model may be overly simplistic, as our sampling is very fragmentary and admixture patterns are complex, with potentially multiple sources located on both sides of the North 592 Atlantic. The lower coral abundance and available habitat in the Mid-Atlantic site compared to 
the NE Atlantic margins may have further contributed to post-colonisation drift. More detailed analyses of the Atlantic CWC, including analyses of samples from more locations, are needed to clarify the North Atlantic phylogeography of the deep-sea.

596 The timing difference in the High latitude colonisation of $L$. pertusa and $M$. oculata may be 597 linked to differences in environmental tolerance. According to ABC analysis, $L$. pertusa 598 reached high latitudes at the end of the LGM (c. $21 \mathrm{ka} ; 9-29 \mathrm{ka})$, whereas the genetic 599 footprints of a possible colonisation of higher latitudes by the SE Rockall populations of $M$. 600 oculata suggest a much more recent event (c. $0.3 \mathrm{ka}, 0.07-3 \mathrm{ka})$. In fact, L. pertusa has 601 thermal acclimation via respiration and calcification mechanisms that are absent in M. oculata (Nauman et al., 2014), and L. pertusa's relative abundance increases from the Mediterranean to Icelandic waters (Arnaud-Haond et al., 2017). The Holocene colonisation of the high latitudes of Europe (e.g., Norway; Fig. 1) is well documented (Schröder-Ritzrau et al., 2005).

In any case, $A B C$ model-based inferences rely on assumptions that cannot easily be controlled in natural populations. Our findings should be interpreted as probable hypotheses rather than clear evidence of past demographic events and detailed roads of colonization. Further theoretical and experimental work that can contribute to a better understanding of CWC phylogeography and connectivity (e.g., early life history traits) is needed. Analyses making use of more widespread samples at the Atlantic scale and high-density data will allow the reconstruction of the phylogeographic history of CWC with more precision. Moreover, our study highlights the need to explore the genetic nature of CWC in the western Mediterranean (Alboran Sea) and the Gulf of Cadiz to determine their possible contributions to larval connectivity and past re-colonisation of the NE Atlantic.

Conclusion The genetic data presented here from deep-sea corals from European margins provide new insights into CWC population history. Our results support a northward post-Last Glacial Maximum expansion of Lophelia pertusa and Madrepora oculata from the West Mediterranean Sea into the NE Atlantic margin. While the moderate to high gene flow of $L$. pertusa homogenized nearly the whole Atlantic genetic pool, M. oculata seems to have progressed slower than L. pertusa, particularly in High latitudes and might have been additionally recolonised from other areas. According to the present estimations, L. pertusa expanded swiftly along the NE Atlantic at a rate of 0.7 to $2 \mathrm{~km}$ per year (considering $4,000 \mathrm{~km}$ of expansion in the past 10 to $30 \mathrm{ka}$ ). The period of Atlantic-Mediterranean separation led to strong genetic differentiation between extant coral populations in the respective regions. This differentiation can be explained by either a founder effect at the NE Atlantic or an unsampled genetic source in the Mediterranean Sea or around NW Africa. The remarkable mosaic of distinct genotypes of $M$. oculata supports the existence of a more complex history, shaped by putative cryptic refugia, admixture, possible different dispersal abilities and reproductive (in)compatibilities. Because of current data limitations, it is not yet possible to determine the most important factor underlying the apparent lack of gene flow along the European margin for M. oculata populations. Further CWC samples from the North Atlantic are needed in order to better understand the extent to which these signals of migration and admixture are representative of North Atlantic CWC as a whole. Nonetheless, the contrasting patterns of genetic diversity observed here strongly support differing presentday dispersals of $L$. pertusa and $M$. oculata and that past environmental changes had different influences on these CWC species. Our study provides an important warning for managers that even taxa with seemingly similar ecological roles, geographic distributions and tolerances may differ in their response to global change. Therefore, multi-species models are required to ensure conservation measures, such as truly representative and connected networks of marine protected Areas. 
642 Author contributions: RB, SAH and JRHB conceived the ideas; RB, SAH, JRHB, NF, MT, AS, 643 AG and ALM, carried out fieldwork; RB, SAH, JRHB, JFB collected the data; RB, SAH, $644 \mathrm{JRHB}, \mathrm{MC}, \mathrm{JFB}$ and NF analysed the data; JRHB, RB and SAH led the writing. All authors 645 read and approved the final manuscript.

\section{Data Accessibility Statement}

647 Microsatellite and sequence data are accessible online at GenBank under accession 648 numbers SUB5134195 and SUB5108670; and on DRYAD . 
Table 1 - Genetic diversity at microsatellite loci for North-East Atlantic Lophelia pertusa. $\mathrm{n}$ - sample size; Âr - allelic richness; Âr(5) standardized allelic richness to the lowest sample size $(\mathrm{N}=5)$; Âp - private allelic richness; He and Ho - expected and observed heterozygosity respectively; Fis - departure from HWE. P-values below $0.05,0.01$ and 0.001 are represented by ${ }^{*},{ }^{* *}$ and ${ }^{* \star *}$, respectively.

\begin{tabular}{|c|c|c|c|c|c|c|c|c|}
\hline Region & Site & $\mathrm{n}$ & $\hat{A} r$ & $\hat{A} r(5)$ & $\hat{A} p$ & $\mathrm{He}$ & Ho & Fis \\
\hline Eastern Mediterranean Sea & Santa Maria di Leuca (SML) & 12 & 8.1 & $6.0 \pm 0.2$ & 4 & $0.80 \pm 0.06$ & $0.71 \pm 0.31$ & $0.15^{\star \star \star}$ \\
\hline Western Mediterranean Sea & Lacaze-Duthiers canyon (LCD) & 7 & 4.9 & $4.9 \pm 0.00$ & 2 & $0.72 \pm 0.13$ & $0.84 \pm 0.19$ & -0.10 \\
\hline Bay of Biscay & Croisic canyon (CRS) & 30 & 18.9 & $8.8 \pm 0.12$ & 5 & $0.89 \pm 0.07$ & $0.80 \pm 0.14$ & $0.12^{* \star *}$ \\
\hline Bay of Biscay & Guilvinec canyon (GUI) & 34 & 18.3 & $8.7 \pm 0.12$ & 4 & $0.89 \pm 0.08$ & $0.86 \pm 0.04$ & $0.05^{\star \star}$ \\
\hline Bay of Biscay & Lampaul canyon (LMP) & 7 & 8.8 & $8.8 \pm 0.00$ & 2 & $0.83 \pm 0.09$ & $0.80 \pm 0.19$ & $0.11^{* \star}$ \\
\hline Bay of Biscay & Crozon canyon (CRZ) & 12 & 11.0 & $8.0 \pm 0.13$ & 2 & $0.84 \pm 0.09$ & $0.74 \pm 0.14$ & $0.16^{\star \star \star}$ \\
\hline Bay of Biscay & Morgat-Douarnez canyon (MRG) & 20 & 16.4 & $8.6 \pm 0.16$ & 4 & $0.87 \pm 0.09$ & $0.83 \pm 0.20$ & $0.07^{* *}$ \\
\hline Bay of Biscay & Petite Sole 1 canyon (PS1) & 26 & 17.4 & $8.7 \pm 0.12$ & 5 & $0.88 \pm 0.09$ & $0.83 \pm 0.11$ & $0.07^{\star \star \star}$ \\
\hline Bay of Biscay & Petite Sole 2 canyon (PS2) & 27 & 17.5 & $8.9 \pm 0.10$ & 4 & $0.90 \pm 0.06$ & $0.85 \pm 0.09$ & $0.07^{\star \star \star}$ \\
\hline SE Rockall bank & Logachev Mounds (LOG) & 22 & 14.8 & $8.1 \pm 0.12$ & 2 & $0.87 \pm 0.07$ & $0.77 \pm 0.13$ & $0.14^{\star \star \star}$ \\
\hline High latitudes & Londsjup 1 (LON1) & 7 & 8.5 & $8.5 \pm 0.00$ & 1 & $0.82 \pm 0.09$ & $0.77 \pm 0.15$ & $0.14^{\star \star}$ \\
\hline High latitudes & Londsjup 2 (LON2) & 20 & 14.5 & $8.2 \pm 0.12$ & 4 & $0.86 \pm 0.10$ & $0.74 \pm 0.16$ & $0.17^{\star \star \star}$ \\
\hline High latitudes & Hafadsjup (HAF) & 16 & 13.6 & $8.5 \pm 0.12$ & 1 & $0.89 \pm 0.05$ & $0.70 \pm 0.22$ & $0.25^{\star \star \star}$ \\
\hline
\end{tabular}

Table 2 - Genetic diversity at microsatellite loci for North-East Atlantic Madrepora oculata. $\mathrm{n}$ - sample size; Âr - allelic richness; Âr(5) standardized allelic richness to the lowest sample size $(\mathrm{N}=5)$; Âp - private allelic richness; He and Ho - expected and observed heterozygosity respectively; Fis - departure from HWE. P-values below $0.05,0.01$ and 0.001 are represented by ${ }^{*},{ }^{* *}$ and ${ }^{* * *}$, respectively.

\begin{tabular}{|c|c|c|c|c|c|c|c|c|}
\hline Region & Site & $\mathrm{n}$ & Âr & $\hat{A} r(5)$ & Âp & $\mathrm{He}$ & Ho & Fis \\
\hline Eastern Mediterranean Sea & Montenegro (MNG) & 5 & 2.3 & $2.3 \pm 0.0$ & 2 & $0.31 \pm 0.34$ & $0.27 \pm 0.39$ & 0.26 \\
\hline Western Mediterranean Sea & Lacaze-Duthiers canyon (LCD) & 6 & 3.5 & $3.3 \pm 0.04$ & 4 & $0.45 \pm 0.32$ & $0.56 \pm 0.40$ & -0.16 \\
\hline Mid Atlantic Ocean & Azores (AZO) & 5 & 2.7 & $2.7 \pm 0.0$ & 0 & $0.38 \pm 0.27$ & $0.47 \pm 0.39$ & -0.12 \\
\hline Bay of Biscay & Croisic canyon (CRS) & 39 & 6.3 & $3.7 \pm 0.06$ & 1 & $0.66 \pm 0.10$ & $0.67 \pm 0.13$ & 0.00 \\
\hline Bay of Biscay & Guilvinec canyon (GUI) & 42 & 5.5 & $3.7 \pm 0.06$ & 0 & $0.67 \pm 0.15$ & $0.60 \pm 0.28$ & $0.12^{\star \star \star}$ \\
\hline Bay of Biscay & Lampaul canyon (LMP) & 11 & 3.8 & $3.2 \pm 0.03$ & 1 & $0.56 \pm 0.28$ & $0.58 \pm 0.31$ & 0.02 \\
\hline Bay of Biscay & Morgat-Douarnez canyon (MRG) & 29 & 4.8 & $3.5 \pm 0.05$ & 0 & $0.61 \pm 0.16$ & $0.56 \pm 0.23$ & $0.10^{*}$ \\
\hline Bay of Biscay & Crozon canyon (CRZ) & 23 & 5.5 & $3.5 \pm 0.06$ & 1 & $0.59 \pm 0.24$ & $0.52 \pm 0.27$ & $0.14^{\star \star}$ \\
\hline
\end{tabular}




\begin{tabular}{|c|c|c|c|c|c|c|c|c|}
\hline Bay of Biscay & Petite Sole 1 canyon (PS1) & 23 & 5.2 & $3.6 \pm 0.05$ & 0 & $0.63 \pm 0.16$ & $0.65 \pm 0.21$ & -0.01 \\
\hline Bay of Biscay & Petite Sole 2 canyon (PS2) & 32 & 6.2 & $3.7 \pm 0.08$ & 0 & $0.65 \pm 0.14$ & $0.59 \pm 0.19$ & $0.10^{*}$ \\
\hline SE Rockall bank & Logachev Mounds (LOG) & 24 & 6.0 & $3.5 \pm 0.07$ & 0 & $0.54 \pm 0.30$ & $0.49 \pm 0.31$ & $0.11^{*}$ \\
\hline High latitudes & Londsjup 1 (LON1) & 6 & 3.7 & $3.3 \pm 0.04$ & 0 & $0.45 \pm 0.30$ & $0.39 \pm 0.29$ & $0.22^{*}$ \\
\hline High latitudes & Londsjup 2 (LON2) & 33 & 4.5 & $2.5 \pm 0.06$ & 2 & $0.38 \pm 0.28$ & $0.31 \pm 0.30$ & $0.18^{* *}$ \\
\hline High latitudes & Hafadsjup (HAF) & 17 & 4.5 & $3.1 \pm 0.06$ & 0 & $0.46 \pm 0.32$ & $0.44 \pm 0.34$ & 0.06 \\
\hline
\end{tabular}

Table 3 - Genetic diversity and neutrality tests for the internal transcribed spacer ribosomal sequences at each North-East Atlantic location of Lophelia pertusa. Asterisk (*) - P-values under 0.05. NA - not applicable (Lampaul canyon had no polymorphic sites).

\begin{tabular}{|c|c|c|c|c|c|c|c|c|}
\hline & & $\begin{array}{l}\text { No. } \\
\text { Samples } \\
\text { (n) }\end{array}$ & $\begin{array}{l}\text { No. } \\
\text { Haplotypes }\end{array}$ & $\begin{array}{l}\text { No. } \\
\text { Private } \\
\text { haplotypes }\end{array}$ & $\begin{array}{l}\text { Haplotype } \\
\text { diversity } \\
\text { (H) }\end{array}$ & $\begin{array}{l}\text { Nucleotide } \\
\text { diversity } \\
\text { (п) }\end{array}$ & $\begin{array}{l}\text { Tajima's } \\
\text { D }\end{array}$ & FS \\
\hline \multicolumn{9}{|c|}{ East Mediterranean Sea } \\
\hline & Santa Maria di Leuca (SML) & 15 & 4 & 0 & 0.4476 & 0.0011 & -0.33 & 1.52 \\
\hline \multicolumn{9}{|c|}{ West Mediterranean Sea } \\
\hline \multirow{7}{*}{$\begin{array}{l}\text { Bay of } \\
\text { Biscay }\end{array}$} & Lacaze-Duthiers canyon (LCD) & 7 & 6 & 2 & 0.7143 & 0.0028 & -0.86 & 0.75 \\
\hline & Croisic canyon (CRS) & 21 & 6 & 2 & 0.2714 & 0.0003 & $-1.73^{*}$ & $2.82^{*}$ \\
\hline & $\begin{array}{l}\text { Guilvinec canyon (GUI) } \\
\text { Morgat-Douarnez canyon }\end{array}$ & 23 & 7 & 1 & 0.249 & 0.0004 & $-1.88^{\star}$ & $1.75^{*}$ \\
\hline & (MRG) & 30 & 10 & 4 & 0.2529 & 0.0003 & $-2.01^{*}$ & $3.70^{*}$ \\
\hline & Crozon canyon (CRZ) & 11 & 6 & 2 & 0.6182 & 0.0014 & $-1.85^{\star}$ & -0.92 \\
\hline & Lampaul canyon (LMP) & 7 & 1 & 0 & 0 & NA & NA & NA \\
\hline & Petite Sole1 (PS1) & 28 & 3 & 1 & 0.0909 & 0.0001 & -1.16 & -0.96 \\
\hline \multirow{2}{*}{$\begin{array}{l}\text { SE Rockall } \\
\text { bank }\end{array}$} & Petite Sole2 (PS2) & 22 & 5 & 2 & 0.2063 & 0.0004 & $-1.89^{*}$ & $1.62^{*}$ \\
\hline & Logachev mounds (LOG) & 21 & 5 & 3 & 0.4143 & 0.0006 & -1.22 & -1.01 \\
\hline
\end{tabular}

High 
latitudes

\begin{tabular}{lrrrrrrr} 
Londsjup1 (LON1) & 8 & 4 & 2 & 0.4643 & 0.0007 & -1.45 & -0.30 \\
Londsjup2 (LON2) & 20 & 7 & 2 & 0.5105 & 0.0008 & -1.41 & -1.48 \\
HafadJup (HAF) & 16 & 5 & 1 & 0.4417 & 0.0008 & -1.22 & -0.37 \\
\hline Mean & 14.5 & 5.5 & 1.7 & 0.4 & 0.0008 & -0.78 & -1.50 \\
s.d. & 8.95 & 1.90 & 1.11 & 0.20 & 0.00073 & 0.991 & 1.594 \\
\hline
\end{tabular}

Table 4 - Genetic diversity and neutrality tests for the internal transcribed spacer ribosomal sequences at each North-East Atlantic location of Madrepora oculata. Asterisk (*) - P-values under 0.05. NA - not applicable (Londsjup 2 had no polymorphic sites).

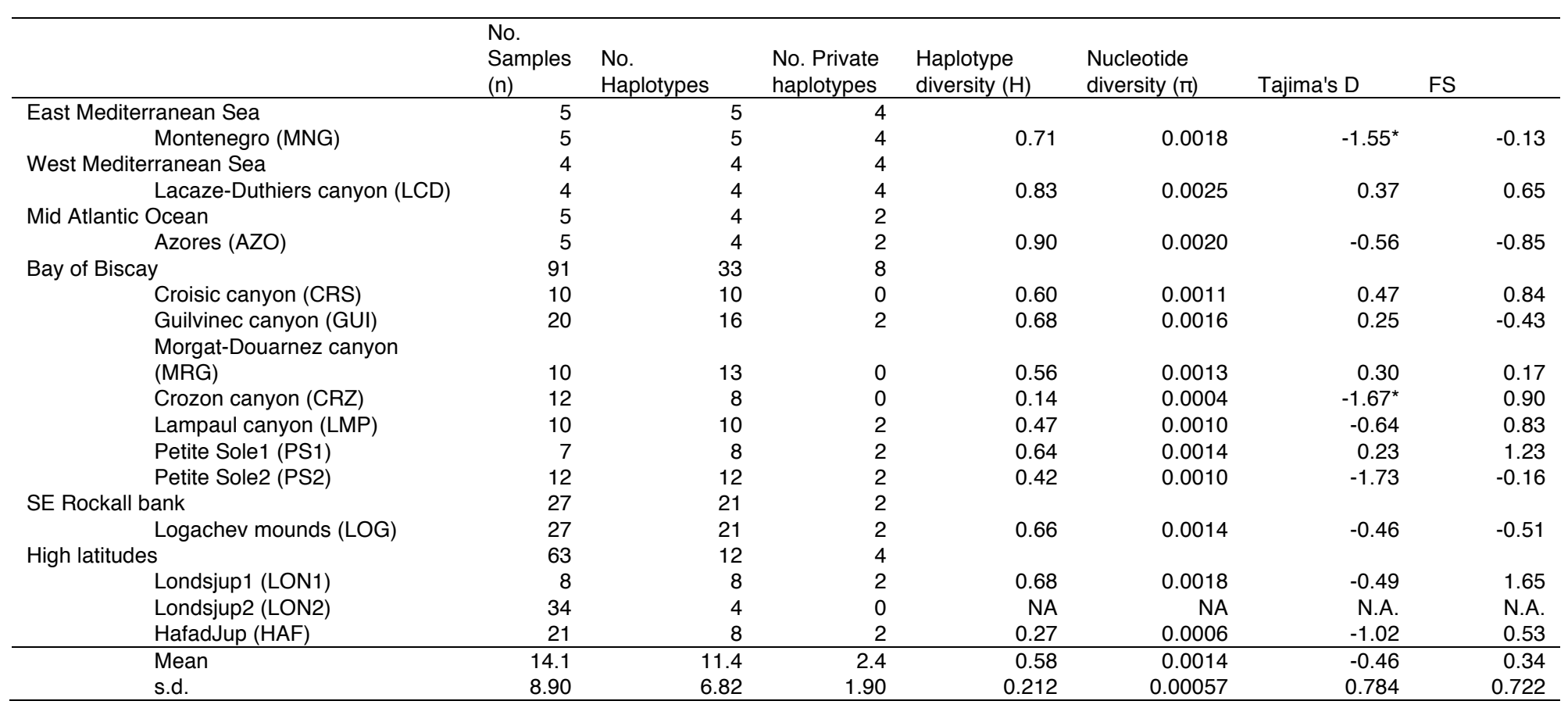


665 Figure 1 - Contemporary distribution of M. oculata (black diamonds) and L. pertusa (grey circles) in the NE Atlantic (2017 UNEP database; http://data.unep-wcmc.org) and the paths of the main North East Atlantic Ocean currents (adapted from Montero-Serrano et al., 2011, Somoza et al., 2014 and Cossa et al., 2018): MOW - Mediterranean Outflow Water; MW Mediterranean Sea Water; NAC - North Atlantic Water; MNAW - Modified North Atlantic Water; EAAIW - Eastern Antarctic Intermediate Water; LSW - Labrador Sea Water; ISOW Iceland-Scotland Overflow Water. Site abbreviations are as in Table 1. Dates correspond to estimated ages for coral mound growth (adapted from Schröder-Ritzrau et al., 2005). Insets are the selected demographic history models for each cold-water coral species. ka thousand years ago. Map was created on QGIS with Mollweide's equal area projection.

675

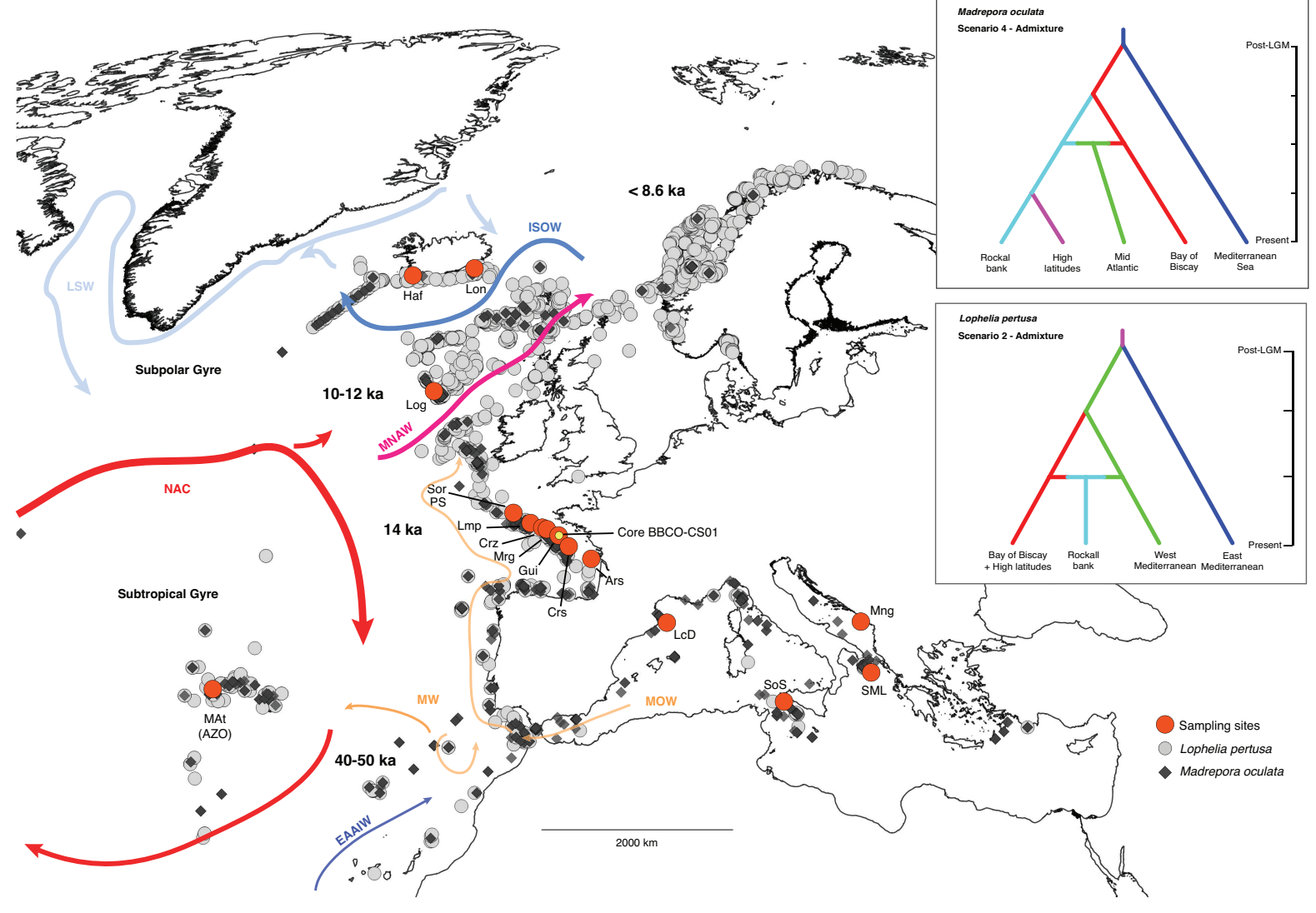

676

677

678

679

680

681

682

683

684 
685 Figure 2 - Genetic subdivisions among regional samples. (a) Microsatellite population 686 ancestry diagrams from TESS displaying the probability of each individual in $\mathrm{K}=4$ clusters 687 for Madrepora oculata (left) and Lophelia pertusa (right) (clusters denoted by different 688 colours). Each individual is depicted by a horizontal line partitioned into K coloured sections, 689 and the length of each section is proportional to the estimated ancestry probability for each 690 cluster. Sample names refer to the sites indicated in Table 1 and Fig. 1. Samples from the 691 Bay of Biscay canyons (left diagram) are geographically ordered from north to south 692 according to Fig. 1. Black horizontal lines separate adjacent sites (MAt - Mid-Atlantic, Med. 693 Mediterranean). (b) Parsimony haplotype networks of internal transcribed spacer ribosomal 694 sequences for M. oculata (left) and L. pertusa (right). The size of the circle is proportional to 695 the observed number of sequences for the corresponding haplotype. Pie charts illustrate the 696 proportion of a haplotype found in each region. The length of links is proportional to the 697 number of mutations separating two haplotypes; the shortest length represents a single 698 mutation. Mediterranean data include eastern and western basin samples. 
a

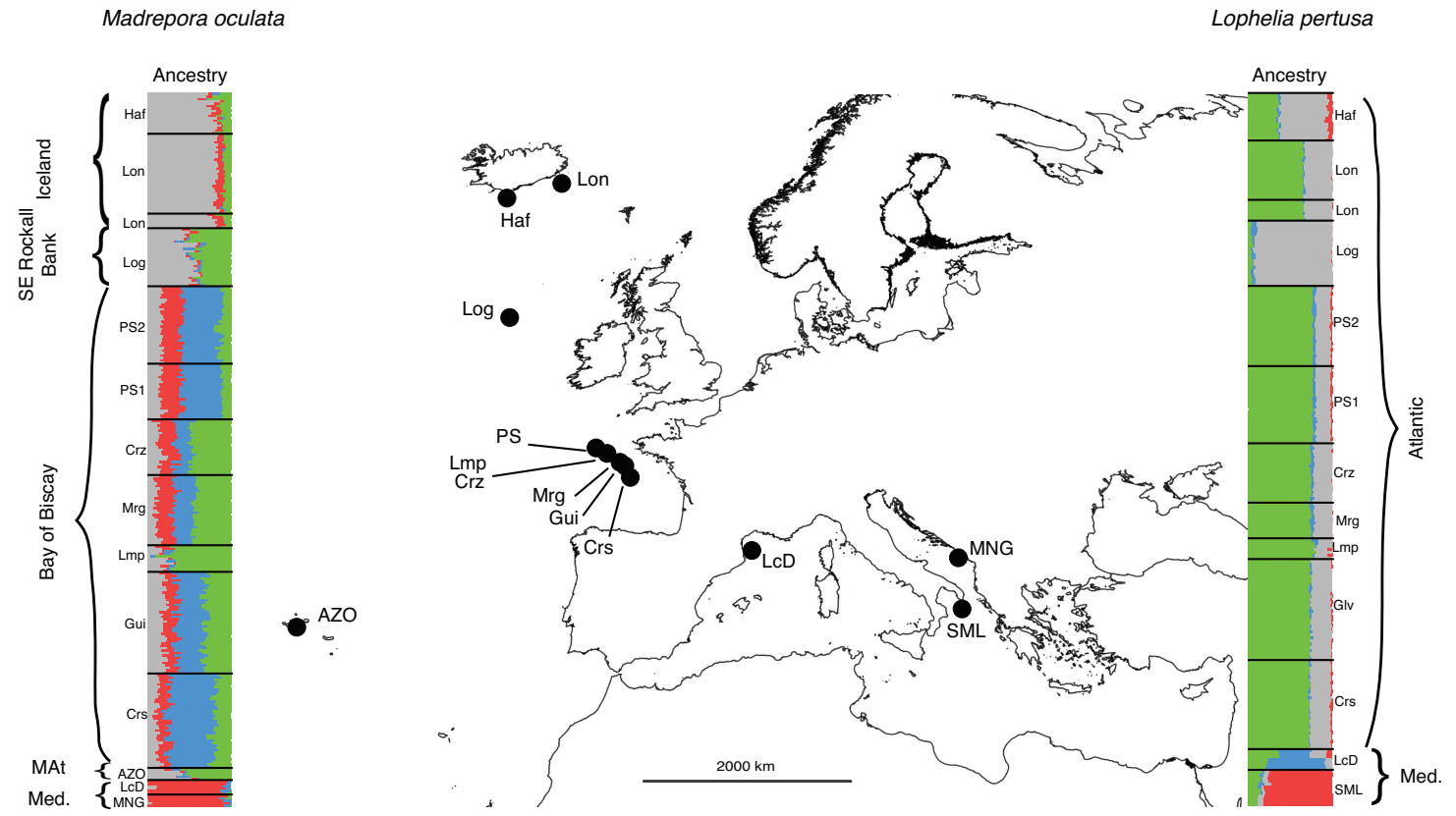

b
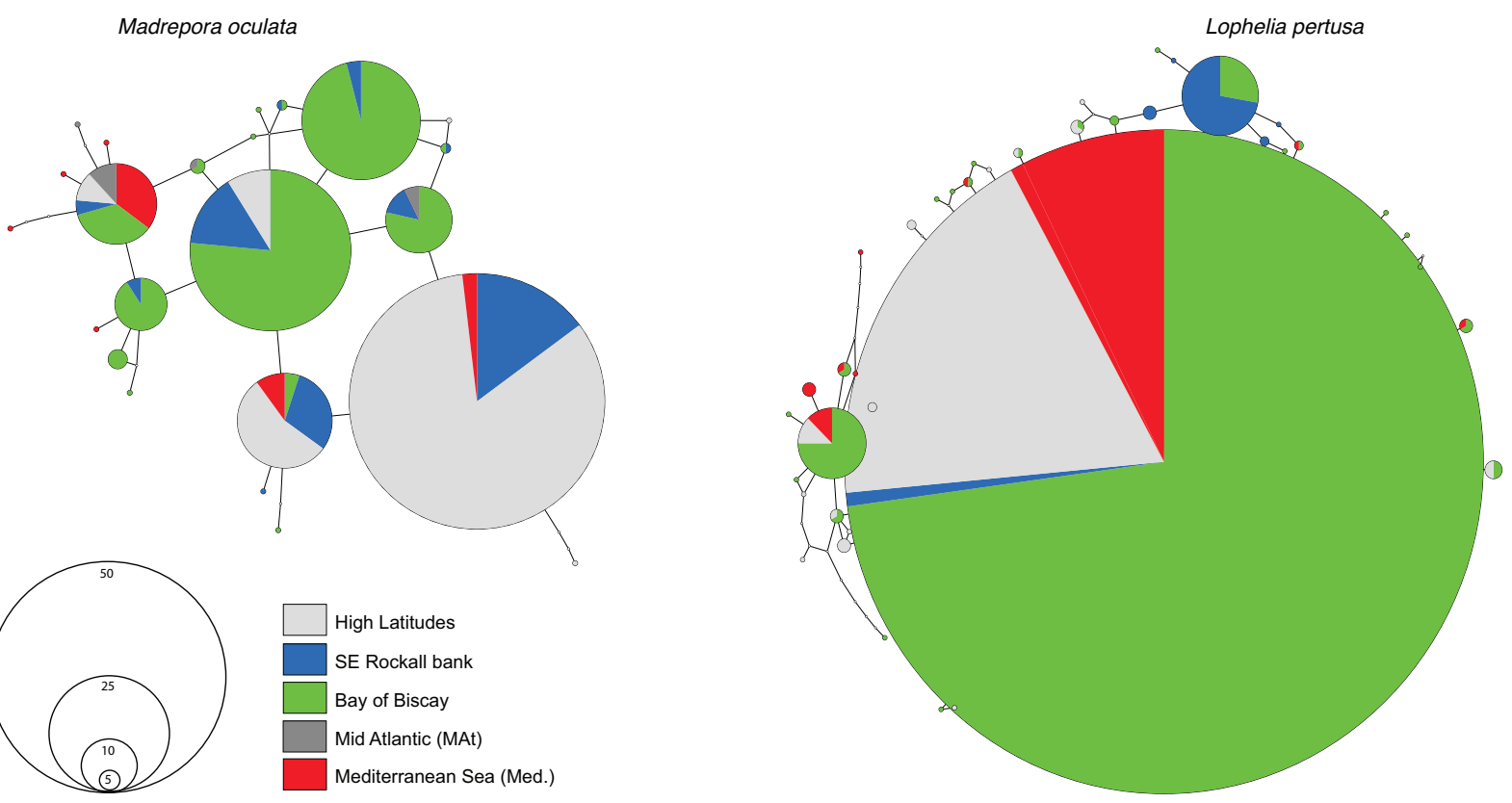

700

701

702

703

704

705

706

707

708 
Figure 3 - Genetic subdivisions among NE Atlantic cold-water coral samples. Top discriminant analyses of principal components (DAPC) for Madrepora oculata and Lophelia pertusa. A minimum-spanning tree based on the squared distances between groups connects group centres (crosses). Insets show the variance explained by the principal components included in the analyses (black). Because the identified optimal number of genetic clusters $(K)$ for $L$. pertusa is $K=2$ (see additional inset with sample density along the first discriminant function), the DAPC plot for $L$. pertusa shows samples colour-coded by sampling site. Bottom - population membership diagrams displaying the probability of each 717 individual colour-coded by sampling site.

a) Madrepora oculata

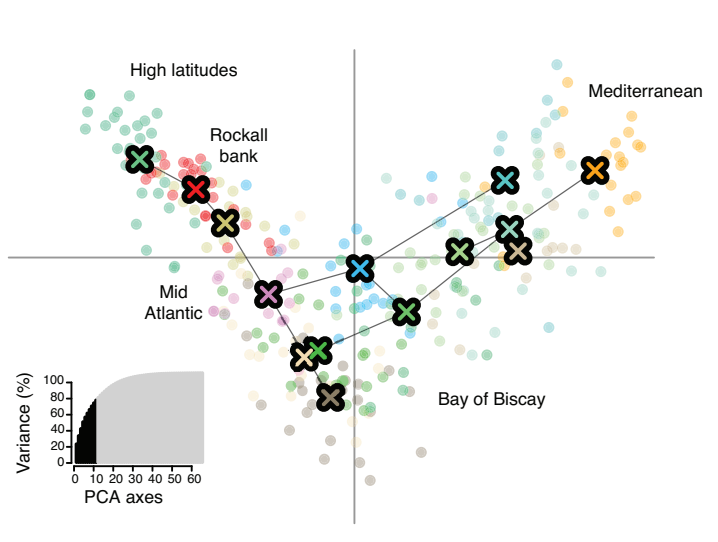

SML LCD AZO CRS GUI MRG CRZ LMP PS1 PS2 LOG LON1 LON2 HAF $\begin{array}{cccc}\text { Mediterranean Mid } & \text { Bay } & \text { Rockall High } \\ \text { Sea Atlantic } & \text { of Biscay } & \text { Bank latitudes }\end{array}$

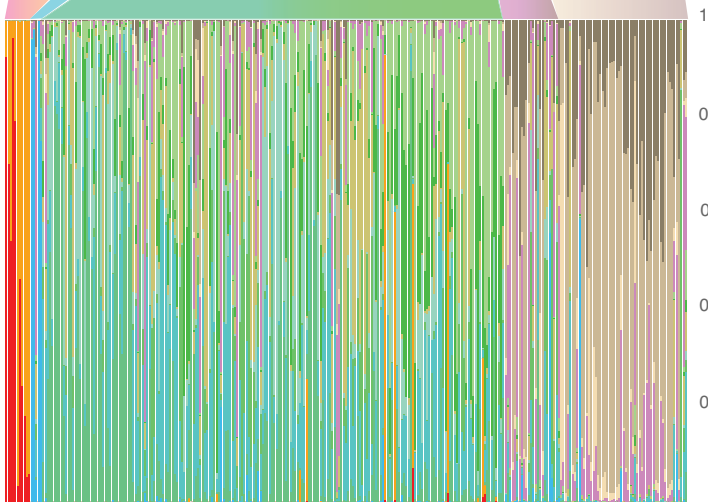

b) Lophelia pertusa
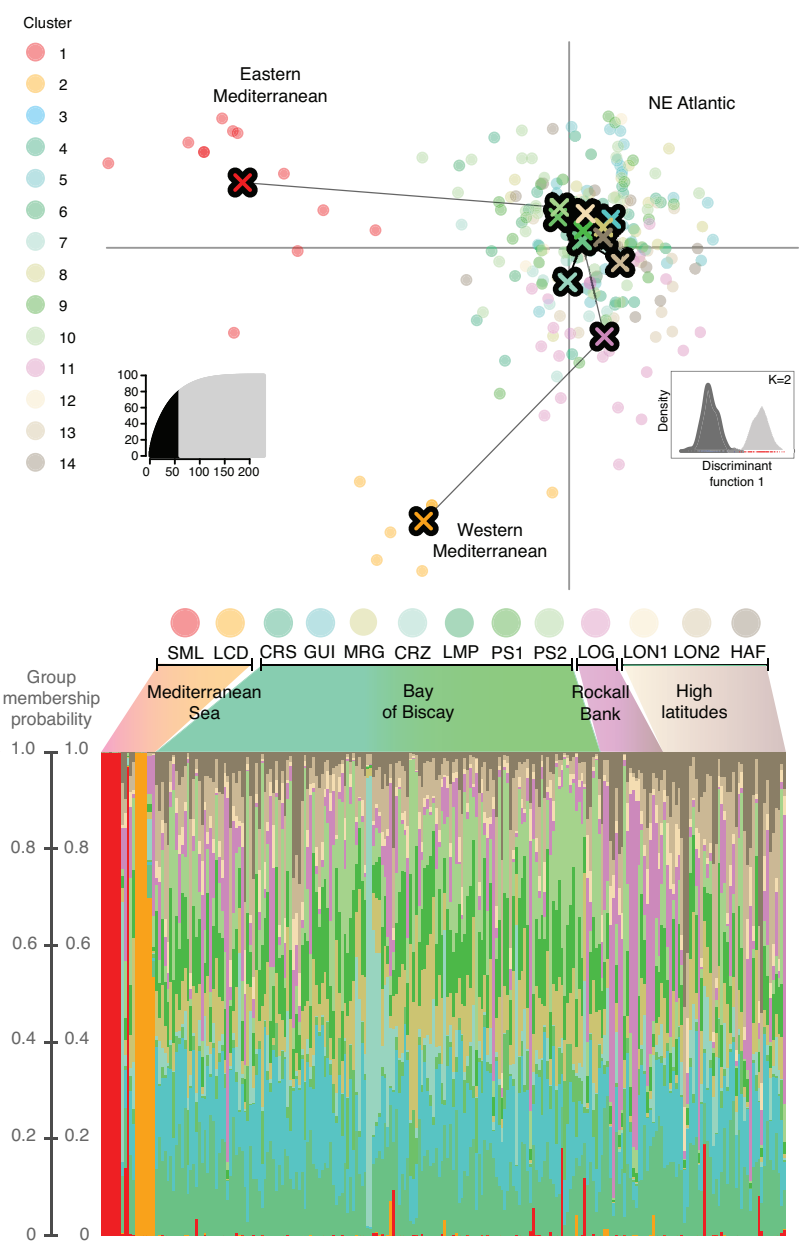


\section{x. References}

730

731

732

733

734

735

736

737

738

739

740

741

742

743

744

745

746

747

748

749

750

751

752

753

754

755

756

757

758

759

760

761

762

763

764

765

766

767

768

769

770

771

772

773

774

775

776

777

778

Arnaud-Haond, S., Van den Beld, I.M.J., Becheler, R., Orejas, C., Menot, L., Frank, N., Grehan, A. \& Bourillet, J.F. (2017) Two "pillars" of cold-water coral reefs along Atlantic European margins: Prevalent association of Madrepora oculata with Lophelia pertusa, from reef to colony scale. Deep-Sea Research Part II: Topical Studies in Oceanography, 145, 110-119.

Becheler, R., Cassone, A.L., Noël, P., Mouchel, O., Morrison, C.L. \& Arnaud-Haond, S. (2017) Low incidence of clonality in cold water corals revealed through the novel use of a standardized protocol adapted to deep sea sampling. Deep-Sea Research Part II: Topical Studies in Oceanography, 145, 120-130.

van den Beld, I.M.J., Bourillet, J.-F., Arnaud-Haond, S., de Chambure, L., Davies, J.S., Guillaumont, B., Olu, K., \& Menot, L. (2017) Cold-Water Coral Habitats in Submarine Canyons of the Bay of Biscay. Frontiers in Marine Science, 4.

Belkhir K., Borsa P., Chikhi L., Raufaste N., B.F. (2004) Genetix 4.05, logiciel sous Windows TM pour la génétique des populations.

Bouchet, P. \& Taviani, M. (1992) The Mediterranean deep-sea fauna: pseudopopulations of Atlantic species? Deep Sea Research Part A, Oceanographic Research Papers, 39, 169-184.

Caye, K., Jay, F., Michel, O., \& François, O. (2016) Fast inference of individual admixture coefficients using geographic data. bioRxiv preprint, 1-35.

Chen, C., Durand, E., Forbes, F. \& François, O. (2007) Bayesian clustering algorithms ascertaining spatial population structure: a new computer program and a comparison study. Molecular Ecology Notes, 7, 747-756.

Clement, M., Posada, D., \& Crandall, K.A. (2000) TCS: A computer program to estimate gene genealogies. Molecular Ecology, 9, 1657-1659.

Clark, P.U. (2009) The Last Glacial Maximum. Science, 325, 710-714.

Cordes, E.E., Jones, D.O., Schlacher, T.., Amon, D.J., Bernardino, A.F., Brooke, S., Carney, R., DeLeo, D.M., Dunlop, K.M., Escobar-Briones, E.G., Gates, A.R., Genio, L., Gobin, J., Henry, L.A., Herrera, S., Hoyt, S., Joye, S., KArk, S., Mestre, N.C., Metaxas, A., Pfeifer, S., Sink, K., Sweetman, A.K. \& Witte, U.F. (2016) Environmental impacts of the deep-water oil and gas industry: a review to guide management strategies. Frontiers in Environmental Science, 4, 1-54.

Cornuet, J.M., Pudlo, P., Veyssier, J., Dehne-Garcia, A., Gautier, M., Leblois, R., Marin, J.M., \& Estoup, A. (2014) DIYABC v2.0: A software to make approximate Bayesian computation inferences about population history using single nucleotide polymorphism, DNA sequence and microsatellite data. Bioinformatics, 30, 1187-1189.

Cossa, D., Heimbürger, L.E., Pérez, F.F., García-lbáñez, M.I., Sonke, J.E., Planquette, H., Lherminier, P., Boutorh, J., Cheize, M., Lukas Menzel Barraqueta, J., Shelley, R., \& Sarthou, G. (2018) Mercury distribution and transport in the North Atlantic Ocean along the GEOTRACES-GA01 transect. Biogeosciences, 15, 2309-2323.

Dahl, M.P., Pereyra, R.T., Lundälv, T. \& André, C. (2012) Fine-scale spatial genetic structure and clonal distribution of the cold-water coral Lophelia pertusa. Coral Reefs, 31, 1135-1148.

Diekmann, O.E., Bak, R.P.M., Stam, W.T. \& Olsen, J.L. (2001) Molecular genetic evidence for probable reticulate speciation in the coral genus Madracis from a Caribbean fringing reef slope. Marine Biology, 139, 221-233.

Doyle, J.J. \& Doyle, J.L. (1988) Natural interspecific hybridization in eastern north-american Claytonia. American Journal of Botany, 75, 1238-1246.

Drummond, A.J., Rambaut, A., Shapiro, B., \& Pybus, O.G. (2005) Bayesian coalescent inference of past population dynamics from molecular sequences. Molecular Biology and Evolution, 22, $1185-1192$.

Dullo, W.C., Flögel, S. \& Rüggeberg, A. (2008) Cold-water coral growth in relation to the hydrography of the Celtic and Nordic European continental margin. Marine Ecology Progress Series, 371 , 165-176. 
Eisele, M., Frank, N., Wienberg, C., Hebbeln, D., López Correa, M., Douville, E. \& Freiwald, A. (2011) Productivity controlled cold-water coral growth periods during the last glacial off Mauritania. Marine Geology, 280, 143-149.

Excoffier, L., Laval, G. \& Schneider, S. (2005) Arlequin (version 3.0): An integrated software package for population genetics data analysis. Evolutionary Bioinformatics Online, 1, 47-50.

Fenberg, P.B., Caselle, J.E., Claudet, J., Clemence, M., Gaines, S.D., Antonio García-Charton, J., Gonçalves, E.J., Grorud-Colvert, K., Guidetti, P., Jenkins, S.R., Jones, P.J.S., Lester, S.E., McAllen, R., Moland, E., Planes, S. \& Sorensen, T.K. (2012) The science of European marine reserves: Status, efficacy, and future needs. Marine Policy, 36, 1012-1021.

Fink, H.G., Wienberg, C., De Pol-Holz, R., Wintersteller, P. \& Hebbeln, D. (2013) Cold-water coral growth in the Alboran Sea related to high productivity during the Late Pleistocene and Holocene. Marine Geology, 339, 71-82.

Flot, J.-F., Dahl, M. \& André, C. (2013) Lophelia pertusa corals from the lonian and Barents seas share identical nuclear ITS2 and near-identical mitochondrial genome sequences. BMC research notes, 6, 144.

François, O., Ancelet, S. \& Guillot, G. (2006) Bayesian clustering using hidden Markov random fields in spatial population genetics. Genetics, 174, 805-16.

Frank, N., Ricard, E., Lutringer-Paquet, A., van der Land, C., Colin, C., Blamart, D., Foubert, A., Van Rooij, D., Henriet, J.P., de Haas, H. \& van Weering, T. (2009) The Holocene occurrence of cold water corals in the NE Atlantic: Implications for coral carbonate mound evolution. Marine Geology, 266, 129-142.

Frank, N., Freiwald, A., Correa, M.L., Wienberg, C., Eisele, M., Hebbeln, D., Van Rooij, D., Henriet, J.P., Colin, C., van Weering, T., de Haas, H., Buhl-Mortensen, P., Roberts, J.M., De Mol, B., Douville, E., Blamart, D., \& Hatte, C. (2011) Northeastern Atlantic cold-water coral reefs and climate. Geology, 39, 743-746.

Fu, Y.X. (1996) New statistical tests of neutrality for DNA samples from a population. Genetics, 143, 557-570.

Henry, L.A., Frank, N., Hebbeln, D., Wienberg, C., Robinson, L., de Flierdt, T. van, Dahl, M., Douarin, M., Morrison, C.L., Correa, M.L., Rogers, A.D., Ruckelshausen, M. \& Roberts, J.M. (2014) Global ocean conveyor lowers extinction risk in the deep sea. Deep-Sea Research Part I: Oceanographic Research Papers, 88, 8-16.

Herrera, S., Shank, T.M. \& Sanchez, J.A. (2012) Spatial and temporal patterns of genetic variation in the widespread antitropical deep-sea coral Paragorgia arborea. Molecular Ecology, 21, 60536067.

Hewitt, G.M. (2004) Genetic consequences of climatic oscillations in the Quaternary. Philosophical Transactions of the Royal Society B: Biological Sciences, 359, 183-195.

Hewitt, G.M. (1999) Post-glacial re-colonisation of European biota. Biological Journal of the Linnean Society, 68, 87-112.

Hewitt, G.M. (1996) Some genetic consequences of ice ages, and their role, in divergence and speciation. Biological Journal of the Linnean Society, 58, 247-276.

Jombart, T. (2008) Adegenet: A R package for the multivariate analysis of genetic markers. Bioinformatics, 24, 1403-1405.

Jombart, T., Devillard, S., \& Balloux, F. (2010) Discriminant analysis of principal components: a new method for the analysis of genetically structured populations. BMC genetics, 11, 94.

Kearse, M., Moir, R., Wilson, A., Stones-Havas, S., Cheung, M., Sturrock, S., Buxton, S., Cooper, A., Markowitz, S., Duran, C., Thierer, T., Ashton, B., Meintjes, P. \& Drummond, A. (2012) Geneious Basic: An integrated and extendable desktop software platform for the organization and analysis of sequence data. Bioinformatics, 28, 1647-1649.

Kitahara, M. V., Cairns, S.D., Stolarski, J., Blair, D., \& Miller, D.J. (2010) A comprehensive phylogenetic analysis of the scleractinia (Cnidaria, Anthozoa) based on mitochondrial $\mathrm{CO} 1$ sequence data. PLOS ONE, 5, e11490. 
Kousteni, V., Kasapidis, P., Kotoulas, G. \& Megalofonou, P. (2015) Strong population genetic structure and contrasting demographic histories for the small-spotted catshark (Scyliorhinus canicula) in the Mediterranean Sea. Heredity, 114, 333-343.

Larsson, A.I., Jarnegren, J., Strömberg, S.M., Dahl, M.P., Lundalv, T. \& Brooke, S. (2014) Embryogenesis and larval biology of the cold-water coral Lophelia pertusa. PLOS ONE, 9.

Lartaud, F., Meistertzheim, A.L., Peru, E. \& Le Bris, N. (2017) In situ growth experiments of reefbuilding cold-water corals: the good, the bad and the ugly. Deep Sea Research Part I: Oceanographic Research Papers, 121, 70-78.

Lartaud, F., Pareige, S., de Rafelis, M., Feuillassier, L., Bideau, M., Peru, E., De la Vega, E., Nedoncelle, K., Romans, P. \& Le Bris, N. (2014) Temporal changes in the growth of two Mediterranean cold-water coral species, in situ and in aquaria. Deep-Sea Research Part II: Topical Studies in Oceanography, 99, 64-70.

LeGoff-Vitry, M.C., Pybus, O.G. \& Rogers, A.D. (2004) Genetic structure of the deep-sea coral Lophelia pertusa in the northeast Atlantic revealed by microsatellites and internal transcribed space sequences. Molecular Ecology, 13, 537-549.

Maggs, C.A., Castilho, R., Foltz, D., Henzler, C., Jolly, M.T., Kelly, J., Olsen, J., Perez, K.E., Stam, W., Väinölä, R., Viard, F. \& Wares, J. (2008) Evaluating signatures of glacial refugia for north atlantic benthic marine taxa. Ecology, 89.

McCulloch, M., Taviani, M., Montagna, P., López Correa, M., Remia, A., \& Mortimer, G. (2010) Proliferation and demise of deep-sea corals in the Mediterranean during the Younger Dryas. Earth and Planetary Science Letters, 298, 143-152.

Meistertzheim, A.L., Lartaud, F., Arnaud-Haond, S., Kalenitchenko, D., Bessalam, M., Le Bris, N. \& Galand, P.E. (2016) Patterns of bacteria-host associations suggest different ecological strategies between two reef building cold-water coral species. Deep-Sea Research Part I: Oceanographic Research Papers, 114, 12-22.

Milligan, R.J., Spence, G., Roberts, J.M. \& Bailey, D.M. (2016) Fish communities associated with coldwater corals vary with depth and substratum type. Deep-Sea Research Part I: Oceanographic Research Papers, 114, 43-54.

De Mol, B., Van Rensbergen, P., Pillen, S., Van Herreweghe, K., Van Rooij, D., McDonnell, A., Huvenne, V., Ivanov, M., Swennen, R. \& Henriet, J.P. (2002) Large deep-water coral banks in the Porcupine Basin, southwest of Ireland. Marine Geology, 188, 193-231.

Montero-Serrano, J.C., Frank, N., Colin, C., Wienberg, C., \& Eisele, M. (2011) The climate influence on the mid-depth Northeast Atlantic gyres viewed by cold-water corals. Geophysical Research Letters, 38, L19604.

Morrison, C.L., Eackles, M.S., Johnson, R.L. \& King, T.L. (2008) Characterization of 13 microsatellite loci for the deep-sea coral, Lophelia pertusa (Linnaeus 1758), from the western North Atlantic Ocean and Gulf of Mexico. Molecular Ecology Resources, 8, 1037-1039.

Morrison, C.L., Ross, S.W., Nizinski, M.S., Brooke, S., Järnegren, J., Waller, R.G., Johnson, R.L. \& King, T.L. (2011) Genetic discontinuity among regional populations of Lophelia pertusa in the North Atlantic Ocean. Conservation Genetics, 12, 713-729.

Morton, B. \& Britton, J.C. (2000) Origins of the Azorean Intertidal Biota: the Significance of Introduced Species, Survivors of Chance Events. Arquipélago. Life and Marine Science, 2, 29-51.

Naumann, M.S., Orejas, C., \& Ferrier-Pagés, C. (2014) Species-specific physiological response by the cold-water corals Lophelia pertusa and Madrepora oculata to variations within their natural temperature range. Deep-Sea Research Part II: Topical Studies in Oceanography, 99, 36-41.

Nei, M. (1978) Estimation of average heterozygosity and genetic distance from a small number of individuals. Genetics, 89, 583-590.

Nei, M. (1987) Molecular Evolutionary Genetics, Columbia University Press, New York, NY.

Petit, R.J., Aguinagalde, I., Beaulieu, J.-L. De, Bittkau, C., Brewer, S., Cheddadi, R., Ennos, R., 
Fineschi, S., Grivet, D., Lascoux, M., Mohanty, A., Muller-Starck, G., Demesure-Musch, B., Palmé, A., Martín, J.P., Rendell, S. \& Vendramin, G.G. (2003) Glacial refugia: Hotspots but not melting pots of genetic diversity. Science, 300, 1563-1565.

Price, J.F., Baringer, M.O., Lueck, R.G., Johnson, G.C., Ambar, I., Parrilla, G., Cantos, A., Kennelly, M.A., \& Sanford, T.B. (1993) Mediterranean Outflow Mixing and Dynamics. Science (New York, N.Y.), 259, 1277-1282.

Pritchard, J.K., Stephens, M. \& Donnelly, P. (2000) Inference of population structure using multilocus genotype data. Genetics, 155, 945-59.

Pusceddu, A., Bianchelli, S., Martín, J., Puig, P., Palanques, A., Masqué, P. \& Danovaro, R. (2014) Chronic and intensive bottom trawling impairs deep-sea biodiversity and ecosystem functioning. Proceedings of the National Academy of Sciences of the United States of America, 111, 8861-6.

Quattrini, A.M., Baums, I.B., Shank, T.M., Morrison, C.L. \& Cordes, E.E. (2015) Testing the depthdifferentiation hypothesis in a deepwater octocoral. Proceedings of the Royal Society B, 282 , 20150008.

Ramos, A., Sanz, J.L., Ramil, F., Agudo, L.M. \& Presas-Navarro, C. (2017) Deep-Sea Ecosystems Off Mauritania. Deep-Sea Ecosystems Off Mauritania (ed. by A. Ramos), J.L. Sanz), and F. Ramil), pp. 481-525. Springer Netherlands.

Repschläger, J., Garbe-Schönberg, D., Weinelt, M., \& Schneider, R. (2017) Holocene evolution of the North Atlantic subsurface transport. Climate of the Past, 13, 333-344.

Rogerson, M., Rohling, E.J., Weaver, P.P.E. \& Murray, J.W. (2004) The Azores Front since the Last Glacial Maximum. Earth and Planetary Science Letters, 222, 779-789.

Sabelli, B. \& Taviani, M. (2014) The making of the Mediterranean Molluscan Biodiversity. The Mediterranean Sea: Its History and Present Challenges (ed. by S. Goffredo) and Z. Dubinsky), pp. 1-678.

Santos, A., Cabezas, M.P., Tavares, A.I., Xavier, R., \& Branco, M. (2015) TcsBU: A tool to extend TCS network layout and visualization. Bioinformatics, 32, 627-628.

Schröder-Ritzrau, A., Freiwald, A. \& Mangini, A. (2005) U/Th-dating of deep-water corals from the eastern North Atlantic and the western Mediterranean Sea. Cold-Water Corals and Ecosystems (ed. by A. Freiwald) and J.M. Roberts), pp. 157-172. Springer-Verlag Berlin Heidelberg.

Shum, P., Pampoulie, C., Kristj, A. \& Mariani, S. (2015) Three-dimensional post-glacial expansion and diversification of an exploited oceanic fish. Molecular Ecology, 24, 3652-3667.

Strömberg, S.M. \& Larsson, A.I. (2017) Larval Behavior and Longevity in the Cold-Water Coral Lophelia pertusa Indicate Potential for Long Distance Dispersal. Frontiers in Marine Science, 4, 32-33.

Stumpf, R., Frank, M., Schönfeld, J. \& Haley, B.A. (2010) Late Quaternary variability of Mediterranean Outflow Water from radiogenic Nd and Pb isotopes. Quaternary Science Reviews, 29, 24622472.

Tajima, F. (1983) Evolutionary relationship of DNA sequences in finite populations. Genetics, 105, 437-460.

Taviani, M., Vertino, A., López Correa, M., Savini, A., de Mol, B., Remia, A., Montagna, P., Angeletti, L., Zibrowius, H., Alves, T., Salomidi, M., Ritt, B. \& Henry, P. (2011) Pleistocene to Recent scleractinian deep-water corals and coral facies in the Eastern Mediterranean. Facies, 57, 579603.

Vertino, A., Stolarski, J., Bosellini, F.R. \& Taviani, M. (2014) Mediterranean Corals Through Time: From Miocene to Present. The Mediterranean Sea: Its History and Present Challenges, 1-678.

Voelker, A.H.L., Lebreiro, S.M., Schönfeld, J., Cacho, I., Erlenkeuser, H. \& Abrantes, F. (2006) Mediterranean outflow strengthening during northern hemisphere coolings: A salt source for the glacial Atlantic? Earth and Planetary Science Letters, 245, 39-55.

Waller, R.G. \& Tyler, P.A. (2005) The reproductive biology of two deep-water, reef-building scleractinians from the NE Atlantic Ocean. Coral Reefs, 24, 514-522. 
Wedding, L.M., Reiter, S.M., Smith, C.R., Gjerde, K.M., Kittinger, J.N., Friedlander, a. M., Gaines, S.D., Clark, M.R., Thurnherr, a. M., Hardy, S.M. \& Crowder, L.B. (2015) Managing mining of the deep seabed. Science, 349, 144-145.

Weinberg, C., Titschack, J., Freiwald, A., Frank, N., Lundälv, T,, Taviani, M., Beuck, L., SchröderRitzrau,, A., Krengel, T. \& Hebbeln, D. (2018) The giant Mauritanian cold-water coral mound province: Oxygen control on coral mound formation. Quaternary Science Reviews, 185,135-152.

Weir, B.S. \& Cockerham, C.C. (1984) Estimating F-statistics for the analysis of population structure. Evolution, 38, 1358-1370.

White, M., Mohn, C., Stigter, H. de, \& Mottram, G. (2005) Deep-water coral development as a function of hydrodynamics and surface productivity around the submarine banks of the Rockall Trough, NE Atlantic. Cold-water Corals and Ecosystems (ed. by A. Freiwald and J.M. Roberts), pp. 503514. Springer, Erlangen Earth Conference Series, Berlin, Heidelberg.

Widmer, A. \& Lexer, C. (2001) Glacial refugia: Sanctuaries for allelic richness, but not for gene diversity. Trends in Ecology and Evolution, 16, 267-269.

Wilson, A.B. \& Eigenmann Veraguth, I. (2010) The impact of Pleistocene glaciation across the range of a widespread European coastal species. Molecular Ecology, 19, 4535-4553.

Zahn, R., Schönfeld, J., Kudrass, H.R., Park, M.H., Erlenkeuser, H. \& Grootes, P. (1997) Thermohaline instability in the North Atlantic during melt water events: Stable isotope and icerafted detritus records from core SO75-26KL, Portuguese margin. Paleoceanography, 12, 696710.

Zibrowius, H. (1980) Les Scléractiniaires de la Méditerranée et de l'Atlantique nord-oriental, Institut Oceanographique Fondation Albert 1er, Prince de Monaco.

\section{xi. Biosketch}

Ronan Becheler is a postdoctoral researcher in evolutionary ecology and population genetics. His research interests concern the evolutionary consequences of reproductive systems, with a special emphasis on partial clonality. He has worked on the assessment of dispersal in coastal and deep-sea species. Currently, he studies the evolution of reproductive strategies and local adaptation in temperate macroalgae.

Joana Boavida is a postdoctoral researcher interested in biodiversity-related disciplines, from taxonomy to biogeography and macroecology, typically using corals as model systems.

\section{xii. Appendices}

The appendix shows supporting information

\section{xiii. Supporting information is supplied in a separate file}

Table S1 - Summary of sampling locations and associated information.

S2 - Additional methods.

Table S3 - Pairwise $F_{S T}$ based on ITS haplotypic frequencies.

Table S4 - Pairwise $F_{S T}$ for microsatellites.

Table S5 - Analysis of molecular variance (AMOVA) for microsatellites. 
968 Table S6 - Analysis of molecular variance (AMOVA) for ITS.

969 Table S7 - Frequency distribution of ITS haplotypes.

$970 \quad$ Figure S6 - Statistical parsimony network.

$971 \quad$ Figure S7 - Tess cross-validation score.

972 Figure S8 - Field picture of fossilised corals from core CS01.

973 Supplementary paleo-history of cold-water coral (CWC) reefs in the Mediterranean Sea and 974 the northeastern Atlantic Ocean.

975 References 